\title{
Impacts of recent decadal changes in Asian aerosols on the East Asian summer monsoon: roles of aerosol-radiation and aerosol-cloud interactions
}

\author{
Buwen Dong ${ }^{1}$ (I) $\cdot$ Laura J. Wilcox $^{1} \cdot$ Eleanor J. Highwood ${ }^{2} \cdot$ Rowan T. Sutton $^{1}$
}

Received: 2 October 2018 / Accepted: 19 February 2019 / Published online: 9 March 2019

(c) The Author(s) 2019

\begin{abstract}
Anthropogenic aerosols (AA) can affect cloud and precipitation through aerosol-radiation interaction (ARI) and aerosolcloud interaction (ACI). Over the past few decades, anthropogenic aerosol emissions have exhibited remarkable changes in the magnitude and in spatial pattern. The most significant changes are the increased emissions over both South Asia and East Asia. In this study, the atmospheric component of a state-of-the-art climate model that includes eight species of tropospheric aerosols, coupled to a multi-level mixed-layer ocean model, has been used to investigate the impacts of Asian anthropogenic aerosol precursor emission changes from 1970s to 2000s on large scale circulation and precipitation in boreal summer over East Asia. Results reveal significant changes in circulation and clouds over East Asia and over the tropical and western North Pacific (WNP). Increased Asian AA emissions lead to anomalous cyclonic circulation over the Maritime continent (MC) and anomalous anticyclonic circulation over the WNP, resulting in anomalous moisture transport convergence over the MC and therefore increased precipitation. They also lead to anomalous moisture flux divergence over both the WNP and large land areas of East Asia, especially over northern China, and therefore decreased precipitation there. These large scale circulation anomalies over the adjacent oceans are related to aerosol change induced ocean feedbacks, predominantly through ACI. It is the slow responses over the adjacent oceans (e.g., SST changes) through coupled atmosphere-ocean interaction in pre-monsoon seasons and summer that shape the changes of the East Asian summer monsoon and local precipitation. The results in this study suggest that increased Asian AA emissions from 1970s to 2000s may have played an important role for the observed southward shift of the Pacific intertropical convergence zone and precipitation belt, weakening of East Asian summer monsoon and reduced precipitation over northern China in East Asia during the latter half of the twentieth century.
\end{abstract}

Keywords Anthropogenic aerosols - Aerosol-radiation interaction · Aerosol-cloud interaction - East Asian summer monsoon · Precipitation

\section{Introduction}

The climate over East Asia is controlled by monsoon circulations with strong seasonal cycles, characterized by a cold dry winter season with low-level northwesterly and northeasterly wind, and a hot rainy summer season with

Buwen Dong

b.dong@reading.ac.uk

1 Department of Meteorology, National Centre for Atmospheric Science, University of Reading, Reading RG6 6BB, UK

2 Department of Meteorology, University of Reading, Reading RG6 6BB, UK low-level southwesterly wind. East Asian monsoon changes have important impacts on local infrastructure, agriculture, local water resources, and the global water cycle (e.g., Wang 2006).

Over the past few decades, there have been large changes in the magnitude and spatial pattern of anthropogenic aerosols (AA) and aerosol precursor emissions, characterized by decreases over Europe and North America, and increases over Asia. Emissions in India continue to increase, while emissions in China have started to level off recently (Lu et al. 2011). Atmospheric aerosols and monsoon circulation over East Asia are strongly coupled. The distribution of aerosol is determined by the atmospheric circulation, and deposition processes, while the circulation is affected by the aerosol (Liu et al. 2011; Tao et al. 
2012; Liao et al. 2015; Wu et al. 2015; Li et al. 2016; Tsai et al. 2016). Aerosol emission changes have the potential to affect both regional and global climate by altering the radiation budget directly and interacting with clouds through microphysical processes, thereby causing subsequent changes in surface temperature, and the local and global hydrological cycle (e.g., Giorgi et al. 2003; Rosenfeld et al. 2008; Stevens and Feingold 2009; Liu et al. 2011; Tao et al. 2012; Levy et al. 2013; Stjern and Kristjansson 2015; Wang et al. 2015; Kim et al. 2016; Xie et al. 2016a, b; Lau and Kim 2017; Li et al. 2016, 2018; Wilcox et al. 2018). As Asian emissions are expected to change substantially in the future an improved understanding of their effects on local climate, and the physical processes underlying their influence on monsoon precipitation, are of great significance for reducing the uncertainties in the future projections of the local and global hydrological cycle (e.g., Allen 2015; Wu et al. 2015).

Because aerosol atmospheric residence time is limited to a few days and aerosol emissions have large spatial variations, aerosol burden is concentrated near its emission regions. This spatial heterogeneity might make aerosol particularly effective in impacting regional climate. By scattering and absorbing solar radiation, aerosol particles can modify the shortwave radiation reaching the earth, which is termed the direct effect or aerosol-radiation interaction (ARI) (Boucher et al. 2013). An important measure of ARI is the aerosol optical depth (AOD) which indicates how much direct sunlight is prevented from reaching the ground by these aerosol particles. Aerosol also interacts directly with cloud by serving as cloud condensation nuclei $(\mathrm{CCN})$ or ice nuclei (IN), leading to changes in cloud droplet number concentration (CDNC), cloud droplet effective radius (CDER), cloud radiative properties, and precipitation efficiency (e.g., Twomey 1977; Rosenfeld et al. 2008, 2014), and therefore the Earth's radiation balance. This is known as the aerosol indirect effects or aerosol-cloud interaction (ACI) (Boucher et al. 2013). The radiative and cloud processes can interact with each other and produce complex aerosol effects on clouds, precipitation, and extreme precipitation, both locally and remotely to emission regions (e.g., Chou et al. 2005; Bollasina et al. 2014; Dong et al. 2016; Tsai et al. 2016; Xie et al. 2016a, b; Wang et al. 2017a; Zhang et al. 2017; Lin et al. 2018; Wilcox et al. 2018).

Previous studies have demonstrated that anthropogenic aerosols are an important driver of changes in the East Asian climate (Liu et al. 2011; Guo et al. 2013; Song et al. 2014; Liao et al. 2015; Wu et al. 2015; Jiang et al. 2015; Stjern and Kristjansson 2015; Wang et al. 2015, 2017a, b, c; Dong et al. 2016; Kim et al. 2016; Zhang and Li 2016; Lau and Kim 2017; Tsai et al. 2016; Zhang et al 2017). However, many questions remain open. In particular, there are important questions about the exact mechanisms and relative roles of
ARI and ACI that govern the response of the Asia climate to local AA emission changes.

The main aims of this study are to understand the role of decadal changes in Asian anthropogenic aerosol emissions from 1970s to 2000s on boreal summer climate over East Asia. In addition, the relative roles of ARI and ACI on model simulated changes are compared and quantified. In particular, this paper addresses: (i) What is the impact of the recent decadal increase in Asian AA precursor emissions on boreal summer climate over East Asia? (ii) What are relative roles of ARI and ACI? These questions are addressed by performing a set of experiments using the atmospheric component of the state-of-the-art HadGEM3 global climate model coupled to a multi-level mixed-layer ocean model.

Most early studies of the influence of AA on the East Asian summer monsoon used either Atmospheric General Circulation Models (AGCMs) (Liu et al. 2011; Guo et al. 2013; Jiang et al. 2015; Wang et al. 2015; Dong et al. 2016; Xie et al. 2016a, b) or Coupled General Circulation Models (CGCMs) (e.g., Bollasina et al. 2014; Song et al. 2014; Stjern and Kristjansson 2015; Tsai et al. 2016; Zhang and Li 2016; Lau and Kim 2017; Wang et al. 2017a, b, c; Zhang et al. 2017). In AGCMs, aerosol induced ocean feedbacks are not considered while the CGCMs exhibit significant biases in the mean state (e.g., Wang et al. 2014). An atmospheric GCM coupled to a multi-level mixed-layer ocean model has much smaller SST biases due to a prescribed flux correction derived from a relaxation experiment, whilst also retaining coupling between the atmosphere and the ocean (e.g., Hirons et al. 2015; Dong et al. 2017; Tian et al. 2018). Therefore, this work is based on a set of experiments using a near-globally coupled atmosphere-ocean-mixed-layer model, MetUM-GOML1 (e.g., Hirons et al. 2015; Dong et al. 2017).

The structure of the paper is as follows. In Sect. 2, the model experiments and model climatology are described briefly. Section 3 presents responses of climate over East Asia to changes in Asian AA emissions when including both ARI and ACI, and quantifies relative roles of ARI and ACI. The role of aerosol induced ocean feedbacks over the Maritime continent is investigated in Sect. 4. Discussions and conclusions are in Sect. 5.

\section{Model and model experiments}

\subsection{Model and experiments}

A set of experiments has been performed using MetUMGOML1 (Hirons et al. 2015), comprising the Met Office Unified Model (MetUM) Global Atmosphere version 3 (GA3; e.g., Hewitt et al. 2011; Walters et al. 2011) at N96 horizontal resolution $\left(1.875^{\circ}\right.$ longitude $\times 1.25^{\circ}$ latitude $)$ with 85 vertical levels coupled to a multi-level mixed-layer ocean 
model. The atmospheric model includes an interactive tropospheric chemistry scheme and eight aerosol species (ammonium sulphate, mineral dust, fossil-fuel black carbon, fossilfuel organic carbon, biomass-burning, ammonium nitrate, sea-salt, and secondary organic aerosols from biogenic emissions). Both aerosol-radiation and aerosol-cloud interactions are considered (Bellouin et al. 2013). The detailed descriptions of the aerosol module and the parameterization of the indirect effects are described in detail by Jones et al. (2011) and Bellouin et al. (2011). The modeled sulphate aerosol surface concentrations, nitrate aerosol concentrations, carbonaceous aerosol concentrations and total AODs are all compares well against observed measurements, suggesting

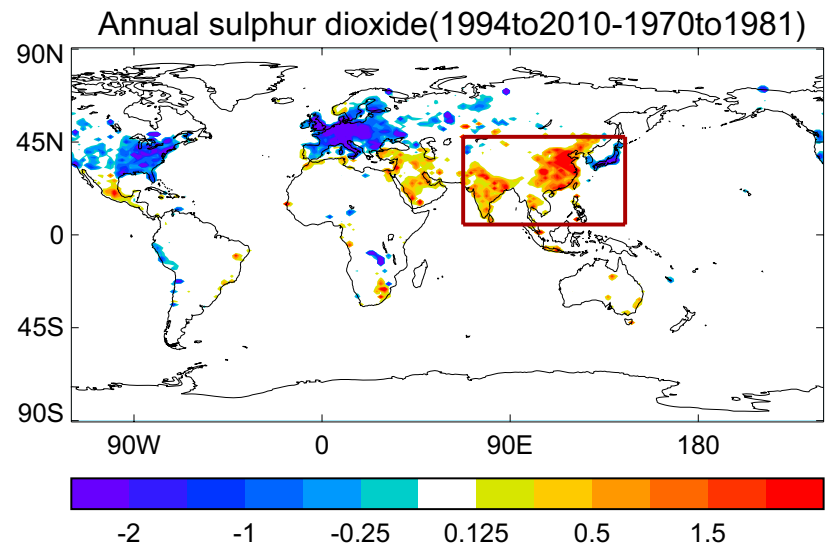

Fig. 1 Changes in annual mean sulphur dioxide emissions $\left(\mathrm{g} \mathrm{m}^{-2}\right.$ year ${ }^{-1}$ ) between the period 1994-2010 and the period 1970-1981 with red box highlighting Asia region (Table 1) a good performance in simulating aerosol properties (e.g., Bellouin et al. 2011).

The oceanic component is a multi-column k profile parameterization (MC-KPP) mixed-layer ocean model. The atmospheric and oceanic components are coupled every $3 \mathrm{~h}$. The air-sea coupling is limited by the maximum extent of a seasonally varying sea ice climatology (Hirons et al. 2015). In the uncoupled region of MetUM-GOML1, the atmosphere is forced by the repeating mean annual cycle of SST and sea ice extent (SIE) from the Met Office HadISST data set (Rayner et al. 2003). Since MC-KPP simulates only vertical mixing and does not include ocean dynamics, climatological seasonal cycles of depth-varying temperature and salinity corrections are prescribed to represent the mean ocean advection and account for biases in atmospheric surface fluxes.

The changes in annual mean sulphur dioxide, the most important aerosol precursor, emissions between two periods of 1994-2010 and 1970-1981 are illustrated in Fig. 1 . The main changes are characterized by decreases over Europe and North America, and increases over Asia. There are also changes in other aerosol emissions such as soot and organic carbon between the two periods (not shown). We focus on the effects of the increased emissions in China and India. The experimental designs are summarized in Table 1. Firstly, a relaxation experiment (E0) is performed in which the MC-KPP profiles of temperature and salinity were relaxed to a present day ocean temperature and salinity climatology derived from the Met Office ocean analysis (Smith and Murphy 2007). The relaxation experiment used present day (PD) GHG and AA forcings (Lamarque et al. 2010, 2011). The daily mean seasonal

Table 1 Summary of numerical experiments

\begin{tabular}{|c|c|c|c|}
\hline \multicolumn{2}{|c|}{ Experiment } & \multirow{2}{*}{$\begin{array}{l}\text { Ocean } \\
\text { Relaxation to "present day" (PD, 1994-2011) mean } \\
\text { 3D ocean temperature and salinity (Smith and Mur- } \\
\text { phy 2007) to diagnose climatological temperature } \\
\text { and salinity tendencies. Sea surface temperature and } \\
\text { sea ice extent are from Rayner et al. (2003) }\end{array}$} & \multirow{2}{*}{$\begin{array}{l}\text { Radiative Forcings } \\
\text { Climatological mean 1994-2010 anthropogenic aerosol } \\
\text { (AA) precursor emissions. 2006-2010 AA from } \\
\text { RCP4.5 scenario (Lamarque et al. 2010, 2011) }\end{array}$} \\
\hline E0 & Relaxation run & & \\
\hline $\mathrm{E} 1$ & ALLF_2000 & $\begin{array}{l}\text { Climatological temperature and salinity tendencies } \\
\text { from experiment R0 }\end{array}$ & $\begin{array}{l}\text { Climatological mean 1994-2010 AA precursor emis- } \\
\text { sions }\end{array}$ \\
\hline $\mathrm{E} 2$ & AER_AISA1970 & As E1 & $\begin{array}{l}\text { Climatological mean 1970-1981 AA precursor emis- } \\
\text { sions over Asia and 1994-2010 AA outside Asia }\end{array}$ \\
\hline E1ARI & ALLF_2000ARI & As E1 & As E1, but aerosol-radiation interaction (ARI) only \\
\hline E2ARI & AER_ASIA1970ARI & As E1 & As E2, but ARI only \\
\hline ACL & AGCM_2000 & $\begin{array}{l}\text { AGCM experiment forced by climatological daily } \\
\text { SSTs from E1 }\end{array}$ & The same radiative forcings as in E1 \\
\hline $\mathrm{AMC}$ & AGCM_2000_MC & $\begin{array}{l}\text { AGCM experiment forced by climatological daily } \\
\text { SSTs from E1 + climatological daily SST change } \\
\text { (E1-E2) over the } \mathrm{MC}\left(20^{\circ} \mathrm{S}-5^{\circ} \mathrm{N}, 100^{\circ} \mathrm{E}-160^{\circ} \mathrm{E} \text {, }\right. \\
\text { ocean only) }\end{array}$ & The same radiative forcings as in E1 \\
\hline
\end{tabular}

GHGs forcing in all experiments are the climatological mean over 1994-2011 
cycle of ocean temperature and salinity corrections are diagnosed from this relaxation experiment and are then imposed in free-running coupled experiments. The CONTROL experiment E1 is forced by the climatological GHG and AA forcings averaged over 1994-2011/2010. E2 is similar to E1 with the same AA emissions outside Asia, but with AA emissions over Asia replaced by the 1970-1981 climatological mean. There are two parallel experiments E1ARI and E2ARI that only consider ARI. To highlight the role of oceanic feedbacks over the Maritime continent (MC), a pair of AGCM experiments with prescribed SSTs have been performed: ACL, forced by climatological daily SSTs and the same radiative forcings from E1; and AMC, with climatological daily SST changes over the MC induced by Asian AA changes added to E1 daily climatological SSTs. All experiments are 32 years long with the last 28 years used for analysis.

The influence of regional AA changes is diagnosed by the difference between a pair of experiments that include and exclude that regional AA changes. For example, the impact of AA changes over Asia is the mean difference between experiments E1 and E2, its impact through ARI is the mean difference between experiment E1ARI and E2ARI. The impact through ACI is estimated by the difference between the total AA impact minus the ARI impact [(E1-E2)-(E1ARI-E2ARI)]. The impact of SST changes over the MC induced by Asian AA changes is the mean difference between experiment AMC and ACL. The statistical significance of the response to a particular forcing in the model is assessed using a two tailed Student's t-test throughout.

\subsection{Model climate over East Asia}

In this section some climatological features of the CONTROL (E1) experiment are compared with observed features. Figure 2a, b show sea level pressure (SLP) from the Hadley Centre's monthly historical mean sea level pressure (HadSLP2) dataset (Allan and Ansell 2006) and $850 \mathrm{hPa}$ wind distribution from the NCEP reanalysis (Kalnay et al. 1996), and the observed rainfall based on GPCP (Adler et al. 2003) whereas Fig. 2c, d show the corresponding model climatologies.

In observations, the existence of the subtropical anticyclone over the western North Pacific (WNP) causes southwesterlies from the Indian Ocean and easterlies from the tropical Pacific Ocean to converge around the Philippines, becoming a strong southerly there (Fig. 2a). This southerly flow transports a large amount of water vapor into East Asia. The anticyclonic circulation in the subtropics over the WNP and south-westerlies over eastern China, Korea and Japan along the western and northern fringes of this anticyclone are reasonably well reproduced in the model (Fig. 2c). However, the westerly from the Indian Ocean is stronger over the Philippines and it extends too far east into the WNP. The monsoon trough also extends too far to the east, and the
Fig. 2 The spatial patterns of JJA climatology for SLP and $850 \mathrm{hPa}$ winds $\left(\mathrm{hPa}, \mathrm{m} \mathrm{s}^{-1}\right)$ and precipitation $\left(\mathrm{mm} \mathrm{day}^{-1}\right)$ in observations $(\mathbf{a}, \mathbf{b})$ and in the model CONTROL (E1) experiment $(\mathbf{c}, \mathbf{d})$ (a) $850 \mathrm{hPa}$ wind and SLP in JJA (NCEP)
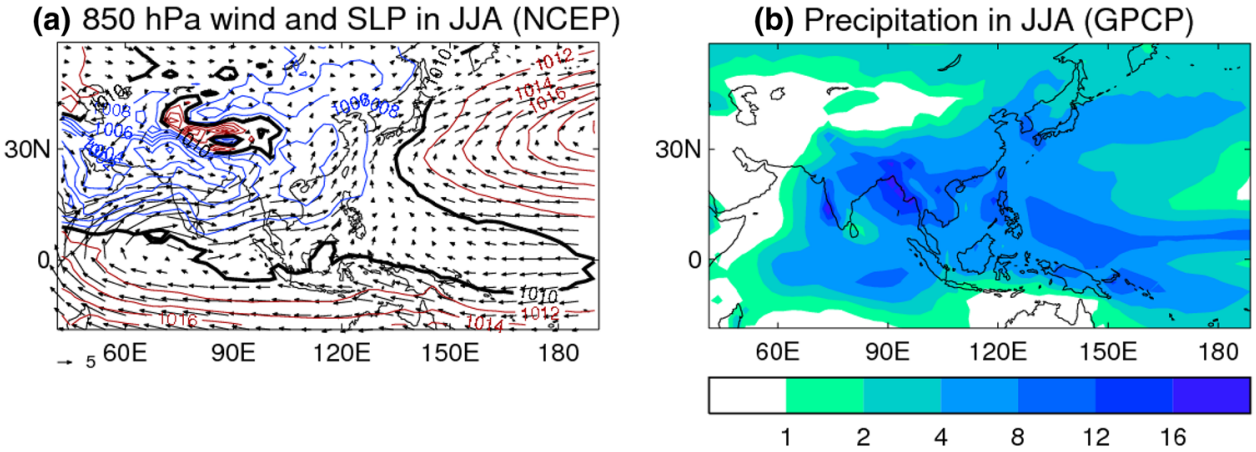

(c) $850 \mathrm{hPa}$ wind and SLP in JJA (GOML1)

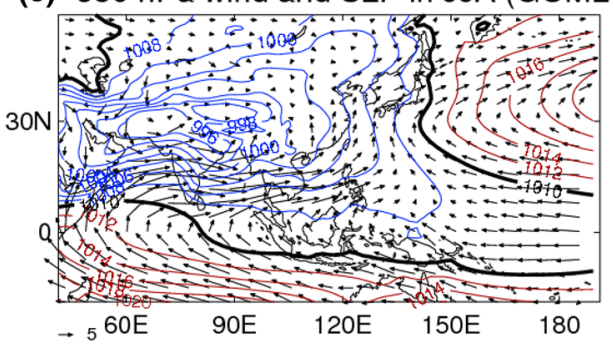

(d) Precipitation in JJA (GOML1)

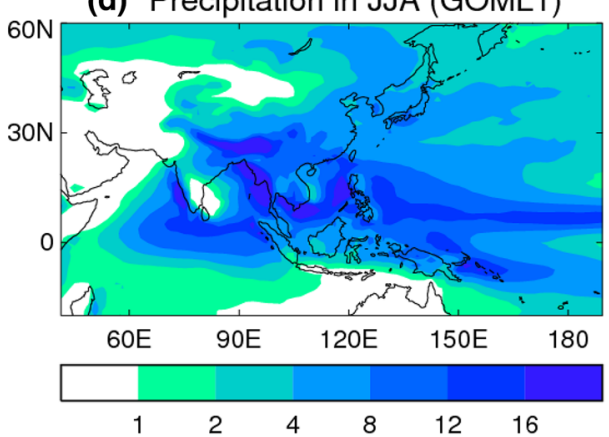


southerly from the South China Sea is relatively weak in the model simulation (Fig. 2c). The weaker southerly in the model is associated with a weak subtropical high over the WNP. The stronger convergence over the Philippines and the tropical western Pacific in the model is also consistent with stronger local rainfall (Fig. 2d).

Compared to observations (Fig. 2b), the model simulation shows a relative lack of precipitation over central India, the Western Ghats, and an extensive area of heavy precipitation over the western Bay of Bengal. It overestimates precipitation over the west equatorial Indian Ocean and the Himalayan foothills (Fig. 2d). Convection tends to be favoured over these latter regions due to the large availability of moisture and heat over the equatorial Indian Ocean and the orographic forcing as the low-level monsoon flow hits the Himalayan foothills respectively. This excessive equatorial Indian Ocean rainfall appears to be an inherent feature of the Met Office Unified model, with preferential model convection over areas with large amounts of available heat and moisture (Martin et al. 2010). This bias is also found in other versions of the Met Office Hadley Centre Global Environmental Model (Levine and Turner 2012; Guo et al. 2013; Sperber et al. 2013; Dong et al. 2016). Despite these deficiencies, the model simulated precipitation and lower tropospheric circulation over East Asia compare well with observations, being consistent with Sperber et al. (2013) who demonstrated that the Hadley Centre Global Environmental Model has a good representation of the summer mean circulation and rainfall distribution over East Asia, which suggests that this model is an appropriate tool to study the response of East Asian climate to a change in regional AA emissions.

\section{Responses of the EASM to Asian AA changes and associated changes in precipitation}

\subsection{Changes in the EASM and precipitation in response to Asian AA changes}

The changes in CDNC, CDER and AOD in the boreal summer (June-August: JJA) in response to Asian AA increases are shown in Fig. 3 and they show significant changes not only over emission regions but also over adjacent oceans. The increased Asian emissions from 1970s to 2000s lead to localized increases in CNDC by about $20 \%$ over both South and East Asia, decreases in CDER by about $10 \%$, and increases in AOD by 0.1-0.3. The decreases in CDNC and weak increases in CDER (Fig. 3a, b) over the Maritime continent (MC) might be the result of increased wet deposition due to local increased precipitation, and this will be discussed in the later section. (a) CDNC in JJA (Asia AA)

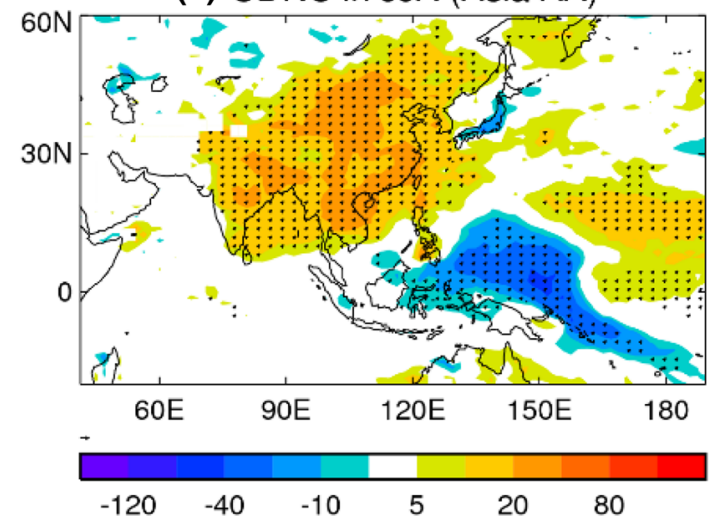

(b) CDER in JJA (Asia AA)

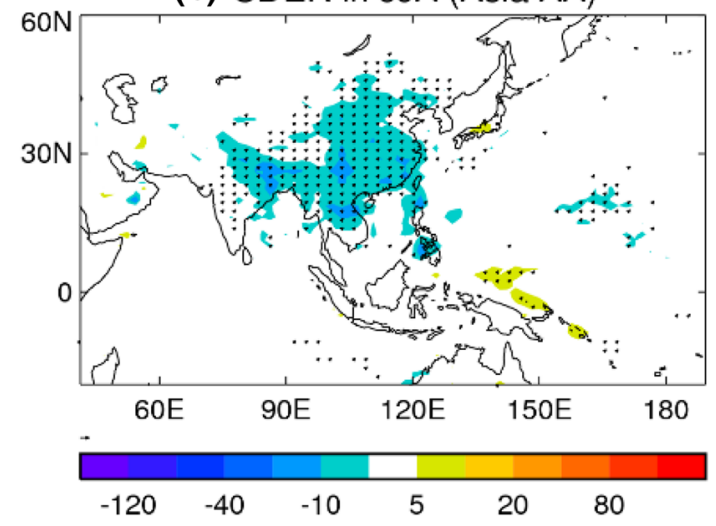

(c) AOD at 0.55 um in JJA (Asia AA)

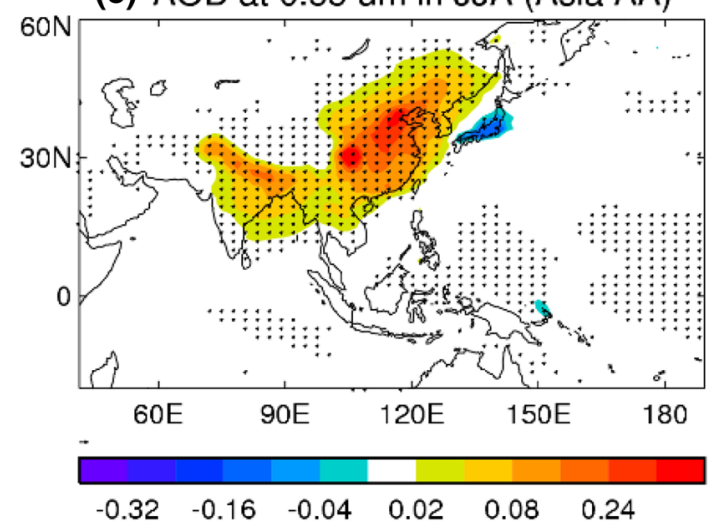

Fig. 3 The spatial patterns of simulated changes in JJA for a cloud droplet number concentration (CDNC), b cloud droplet effective radius (CDER), and $\mathbf{c} A O D$ at $0.55 \mu \mathrm{m}$ in response to changes in Asian AA precursor emissions (E1-E2). Changes in CDCN and CDER are percentage changes relative to the experiment E1. Black dots highlight regions where the changes are statistically significant at the $10 \%$ level using a two-tailed Student's t-test

Simulated changes of some key variables of the surface energy balance, sectorally averaged temperature, vertical velocity and zonal wind, and climate around East Asia in response to Asian AA emission increases, including both 

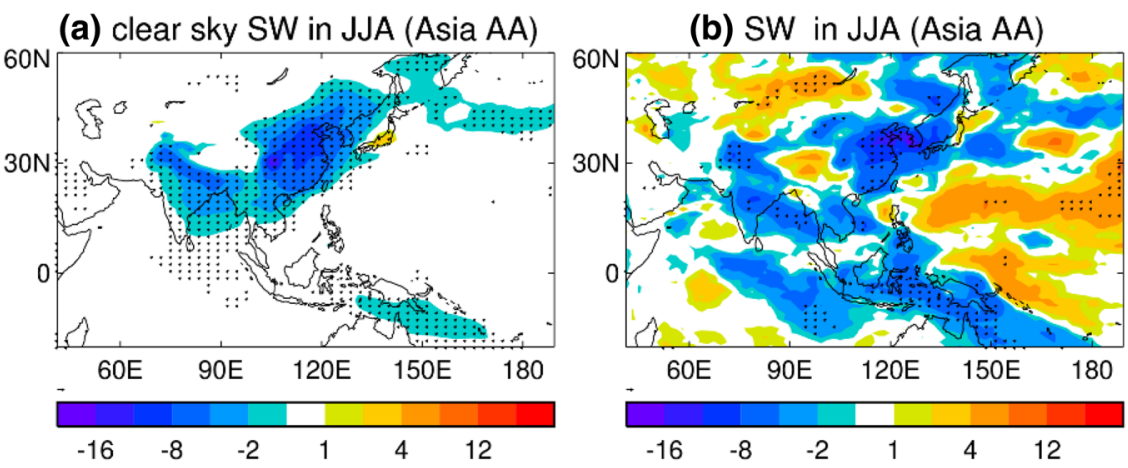

(c) total cloud in JJA (Asia AA)

(d) CRE SW in JJA (Asia AA)

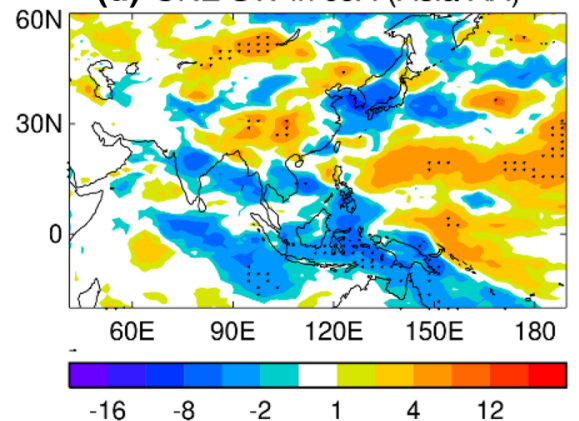

(e) Water vapor in JJA (Asia AA)
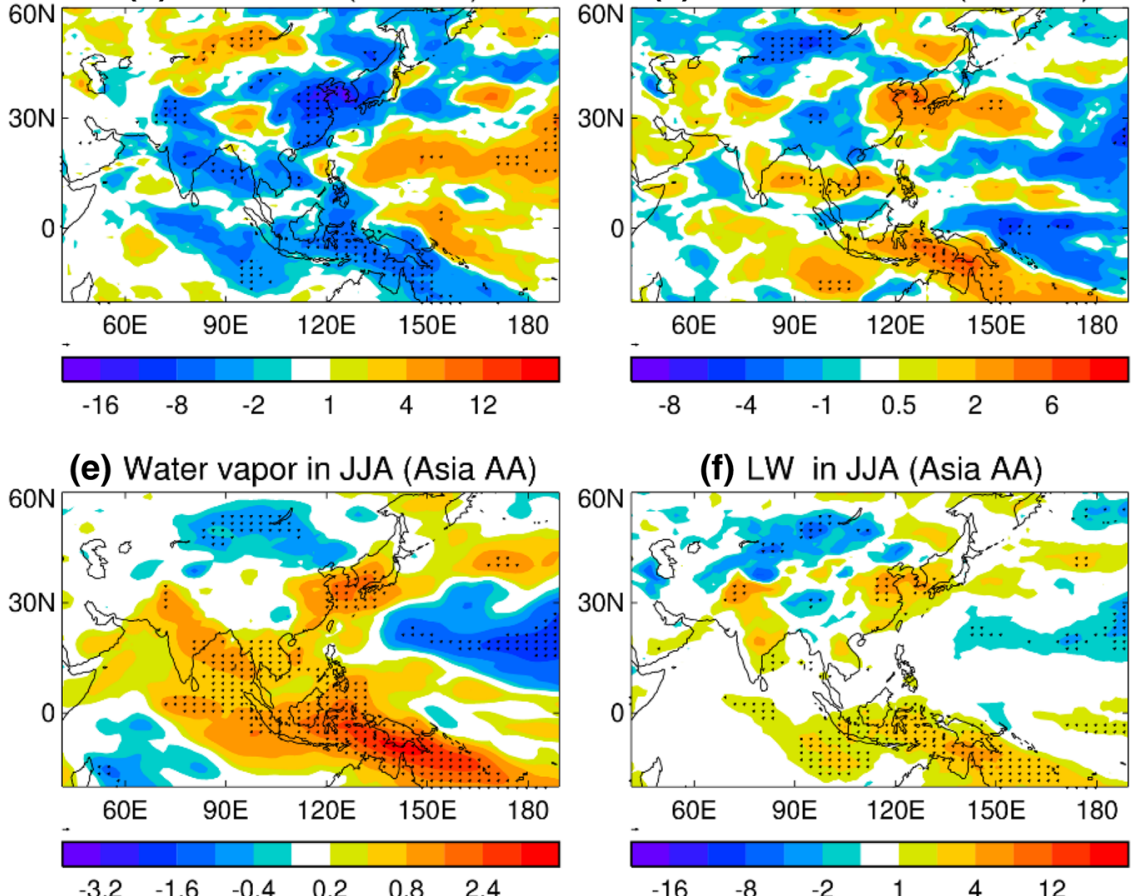

(f) LW in JJA (Asia AA)

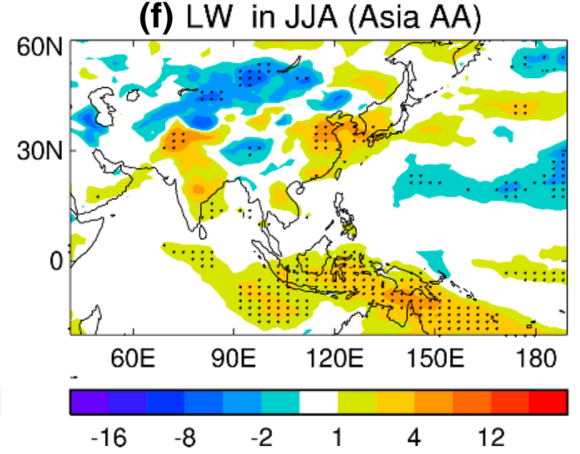

(g) LH \& SH in JJA (Asia AA)

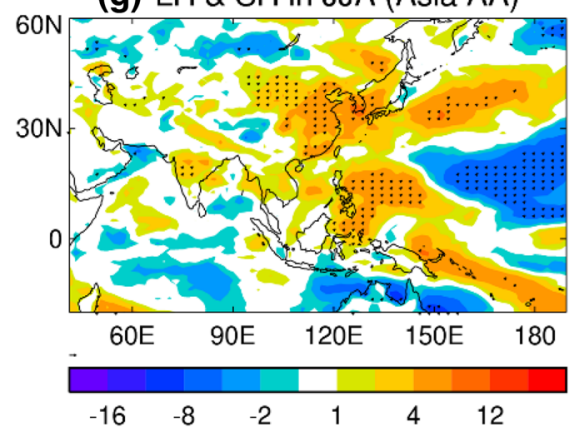

(h) surface temp in JJA (Asia AA)

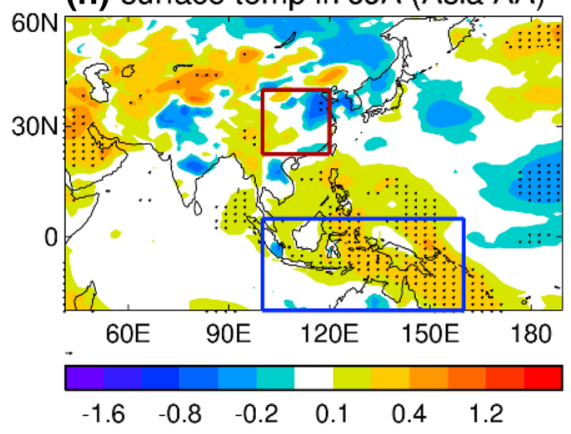

Fig. 4 Spatial patterns of simulated changes in JJA for some variables and surface energy components in response to changes in Asian AA precursor emissions through both ARI and ACI (E1-E2). Radiation and fluxes are in $\mathrm{W} \mathrm{m}^{-2}$ and positive downwards. Cloud cover is in

ARI and ACI, are shown in Figs. 4, 5 and 6. Area averaged mean responses over East Asia (land only) and the Maritime continent (ocean only) are illustrated in Table 2. The most important features are the decreases of clear sky surface shortwave (SW) radiation by $4-8 \mathrm{~W} \mathrm{~m}^{-2}$ over South Asia and East Asia (Fig. 4a; Table 2) resulting from direct scattering by the AA increase. The decrease in all sky surface SW radiation over South Asia is stronger than in the clear sky SW while the decrease over East Asia is weaker than the clear sky surface SW (Fig. 4b). This reflects the role of increased cloud cover over South Asia and decreased cloud cover over a large area of East Asia, leading to positive cloud radiative effect (CRE) anomaly over East Asia and negative anomaly over south Asia (Fig. 4c, d). These differences are
$\%$, and water vapor is in $\mathrm{kg} \mathrm{m}^{-2}$. Black dots highlight regions where the changes are statistically significant at the $10 \%$ level using a twotailed Student's t-test. Red and blue boxes highlight regions of East Asia and the Maritime Continent (MC)

mainly related to changes in circulation (Fig. 6b). Meanwhile, there are significant decreases $\left(4-8 \mathrm{~W} \mathrm{~m}^{-2}\right)$ in surface SW over the Maritime continent, mainly induced by negative anomalies in SW CRE related to increased cloud cover and warming over ocean (Fig. 4c, d, h; Table 2). The warming over the Maritime continent is mainly the result of increased water vapor content (Fig. 4e; Table 2), with additional positive feedbacks from reduced upward turbulent heat flux, resulting from anomalous northeasterly flow (Fig. 6b) which weakens the climatological southwesterly in the region (Fig. 2c). It is the increased surface clear sky LW, associated with increased water vapor in the atmosphere and a decrease of upward latent flux over the Maritime continent, that lead to local surface warming (Fig. 4h). The increases 

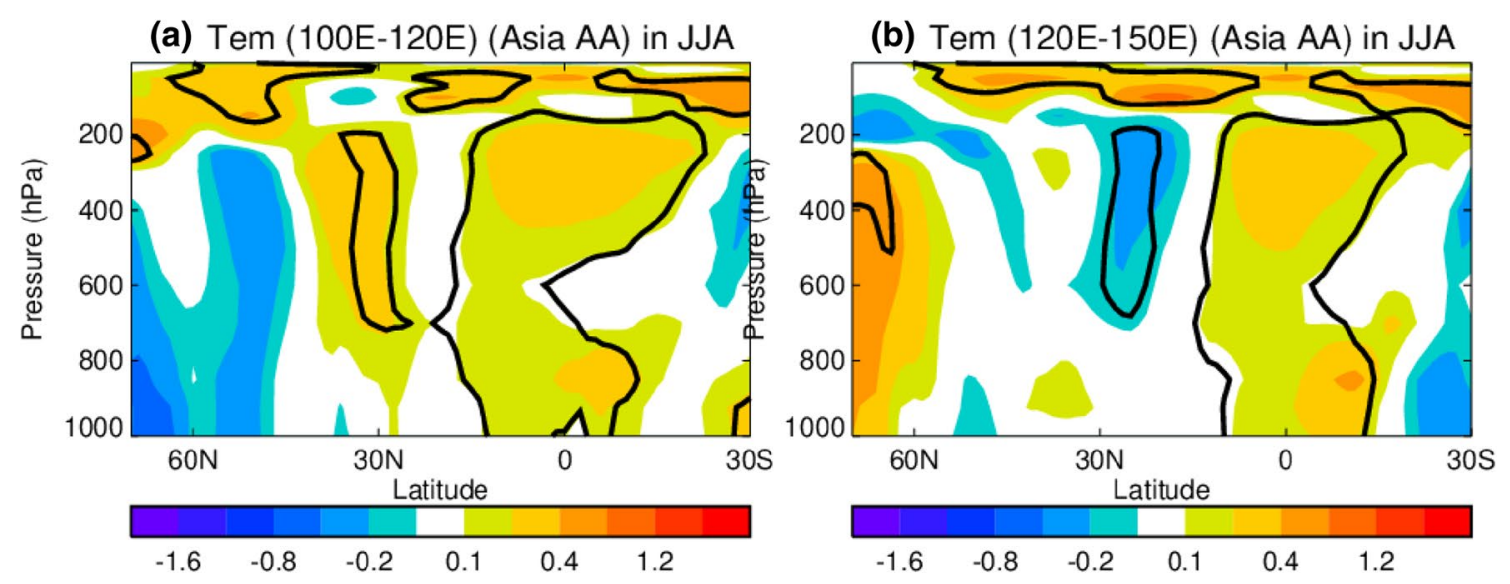

(c) Omega (100E-120E) (Asia AA) in JJA

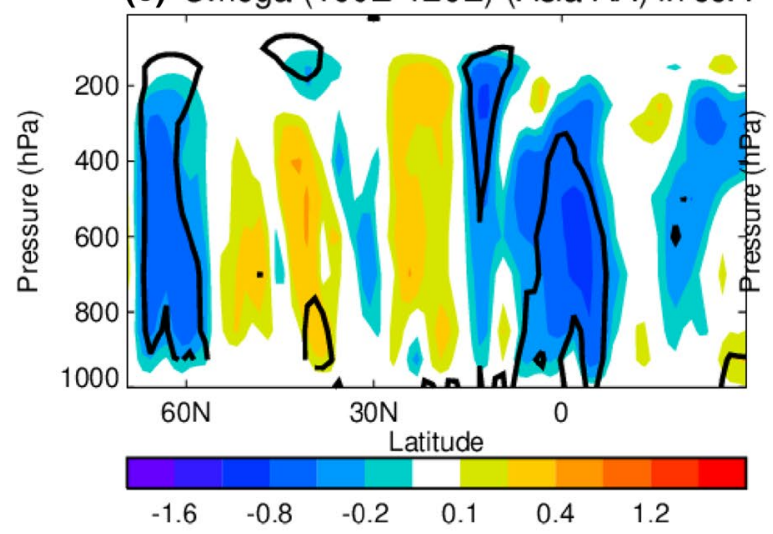

(d) Omega (120E-150E) (Asia AA) in JJA

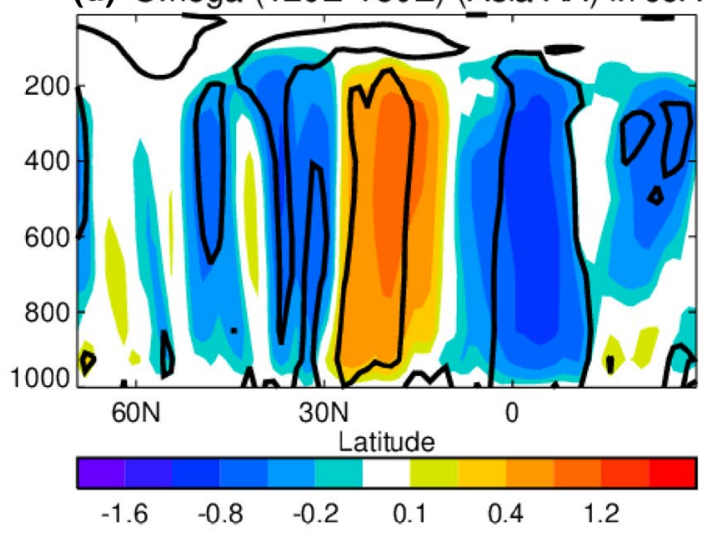

(e) zonal wind (100E-120E) (Asia AA) in JJA

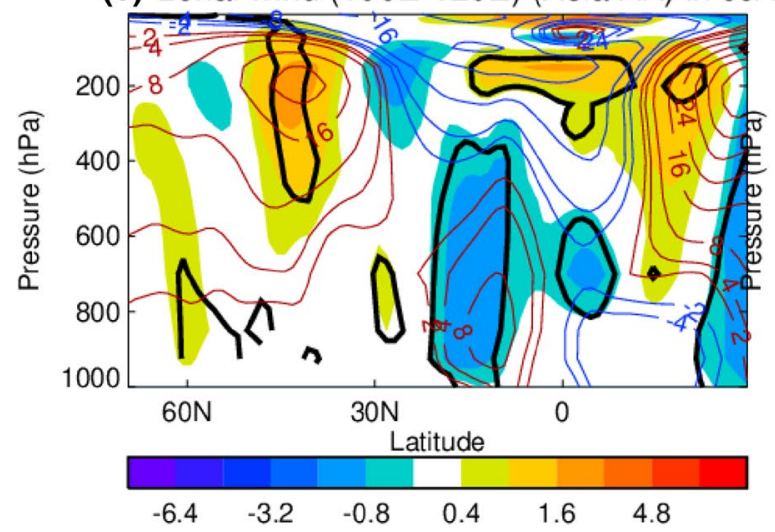

(f) zonal wind (120E-150E) (Asia AA) in JJA

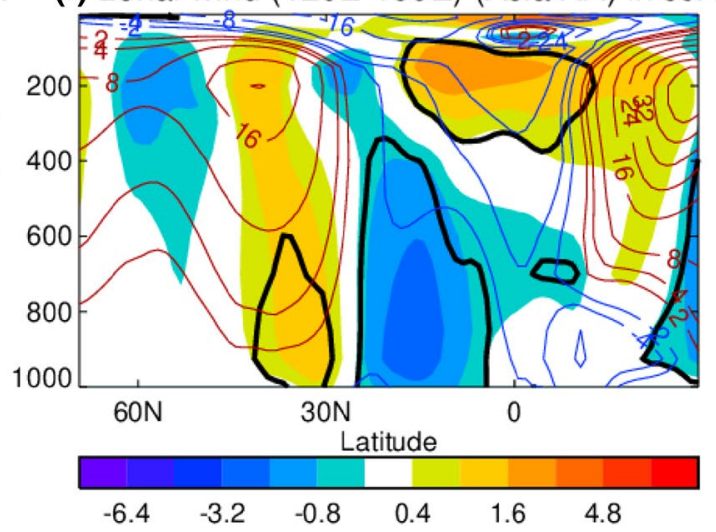

Fig. 5 Zonal averaged changes in JJA for $(\mathbf{a}, \mathbf{b})$ temperature $\left({ }^{\circ} \mathrm{C}\right)$ and $(\mathbf{c}, \mathbf{d})$ vertical velocity $\left(\mathrm{Pa} \times 10^{-2} \mathrm{~s}^{-1}\right)$ over East Asian sector $\left(100^{\circ} \mathrm{E}-120^{\circ} \mathrm{E}\right)$ and over the western Pacific sector $\left(120^{\circ} \mathrm{E}-150^{\circ} \mathrm{E}\right)$ in response to changes in Asian AA precursor emissions through

both ARI and ACI (E1-E2). Black lines highlight regions where the changes are statistically significant at the $10 \%$ level using a two-tailed Student's t-test. Contours in $(\mathbf{e}, \mathbf{f})$ are climatology in the CONTROL (E1) simulation

of surface SW by $2-8 \mathrm{~W} \mathrm{~m}^{-2}$ over the western and tropical Pacific (Fig. 4b) are the result of decreased cloud cover (Fig. 4c), associated with anomalous anticyclonic circulation (Fig. 6b) and a decrease in atmospheric water vapor content (Fig. 4e), and therefore negative anomalies of SW CRE (Fig. 4d).

Zonally averaged responses in temperature indicate warming over the tropics in the troposphere in both Asian and western Pacific sectors (Fig. 5a, b). These free tropospheric warmings are the result of diabatic heating associated with anomalous ascent (Fig. 6c, d) and increased water vapor in the atmosphere (Fig. 4e). Further north in the 
(a) JJA SAT (Asia AA)

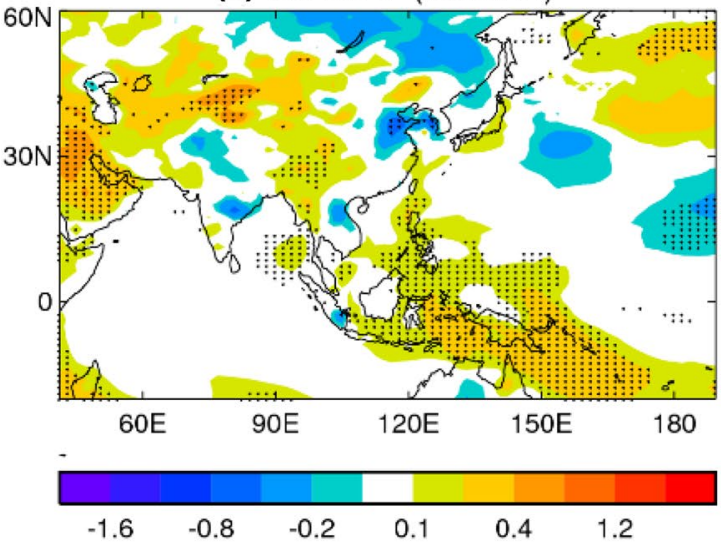

(c) JJA MC and transport (Asia AA)

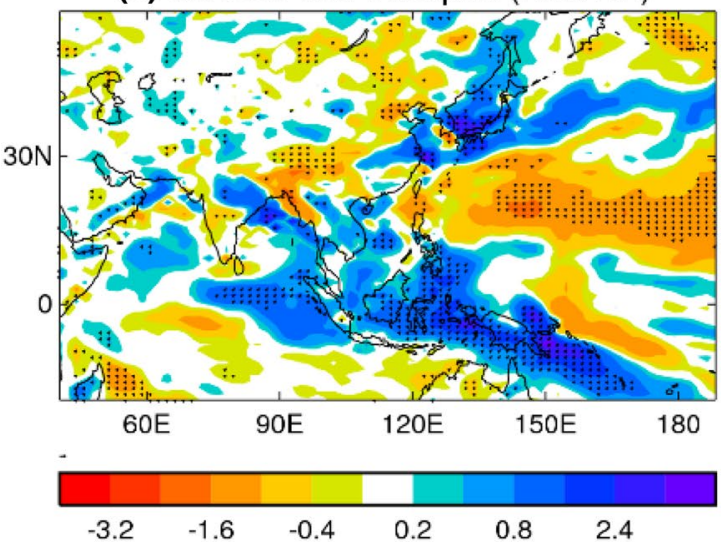

(e) moisture covergenece (dyn) (Asia AA)

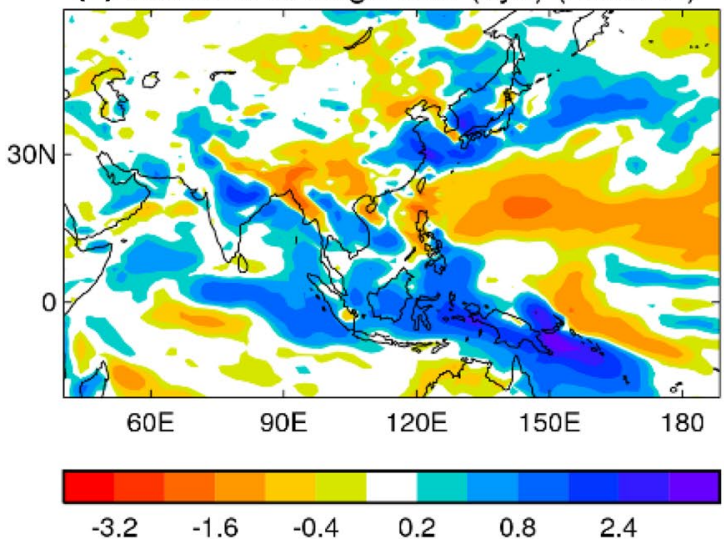

Fig. 6 The spatial patterns of simulated changes in JJA for a SAT $\left({ }^{\circ} \mathrm{C}\right)$, b SLP and $850 \mathrm{hPa}$ wind ( $\mathrm{hPa}$ and $\mathrm{m} \mathrm{s}^{-1}$ ), c vertically integrated moisture flux convergence $\left(\mathrm{kg} \mathrm{m}^{-2} \mathrm{day}^{-1}\right)$, d precipitation $\left(\mathrm{mm}\right.$ day $\left.^{-1}\right)$, e moisture flux convergence due to anomalous circulation $\left(\mathrm{kg} \mathrm{m}^{-2} \mathrm{day}^{-1}\right)$, and $\mathbf{f}$ moisture flux convergence due to anoma-

subtropics is anomalous descent, indicating an anomalous local Hadley circulation. The anomalous descent over East Asia is associated with increased stability in the troposphere (b) JJA SLP and $850 \mathrm{hPa}$ wind (Asia AA)

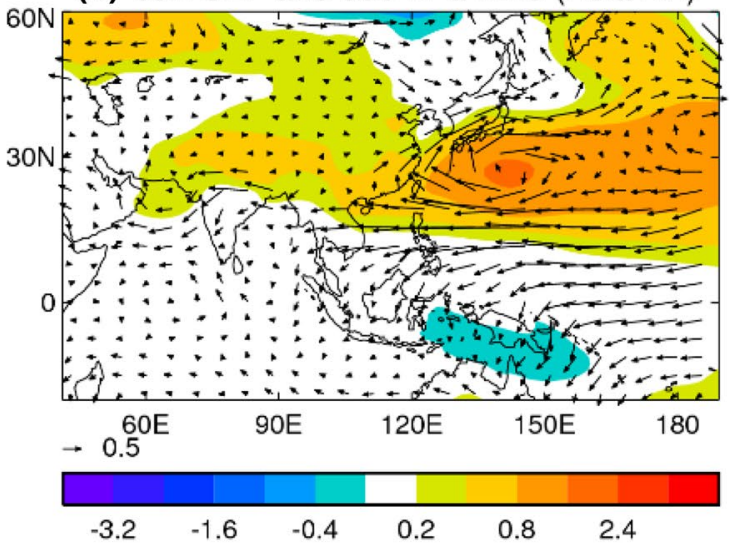

(d) JJA Precipitation change (Asia AA)

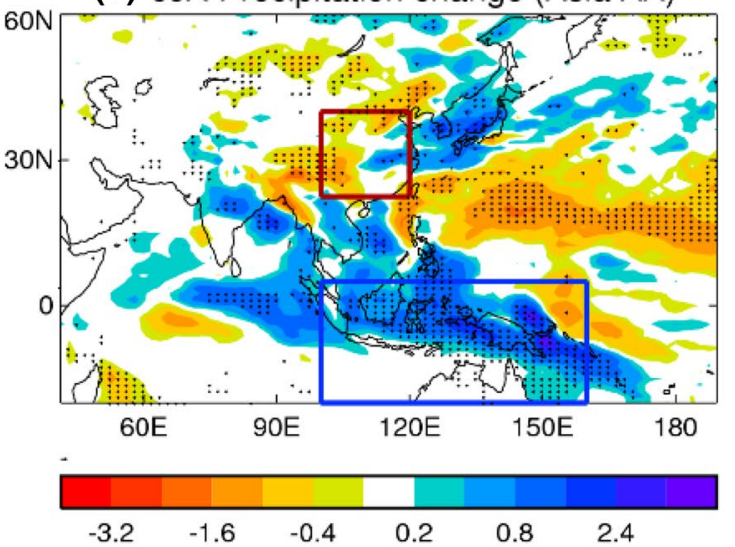

(f) moisture covergenece (thermo) (Asia AA)

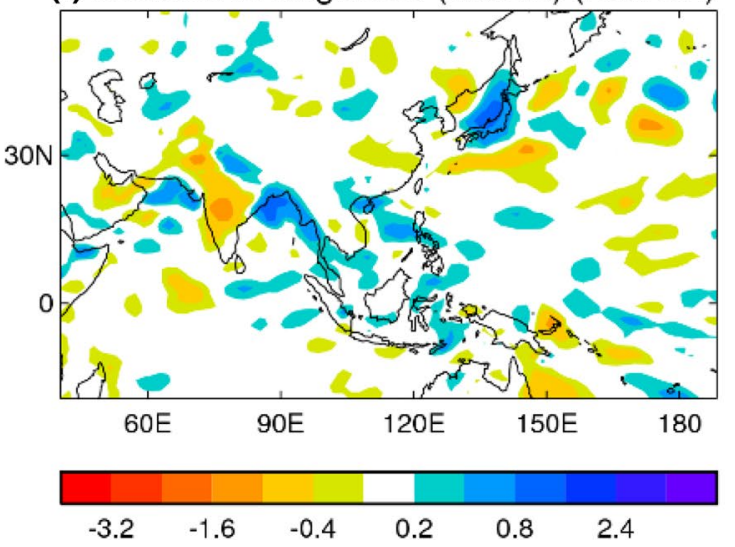

lous humidity $\left(\mathrm{kg} \mathrm{m}^{-2} \mathrm{day}^{-1}\right)$ in response to changes in Asian AA precursor emissions through ARI and ACI (E1-E2). Black dots highlight regions where the changes are statistically significant at the $10 \%$ level using a two-tailed Student's t-test

(Fig. 5a, c), and large anomalous warming in the middle and upper troposphere. This warming might be a result of an increased proportion of black carbon and organic carbon 
Table 2 Area averaged responses for various variables over East Asia $\left(22.5^{\circ} \mathrm{N}-40^{\circ} \mathrm{N}\right.$, $100^{\circ} \mathrm{E}-120^{\circ} \mathrm{E}$, land only) and over the Maritime continent $\left(20^{\circ} \mathrm{S}-5^{\circ} \mathrm{N}, 100^{\circ} \mathrm{E}-160^{\circ} \mathrm{E}\right.$, ocean only) in boreal summer (June-August: JJA)

\begin{tabular}{|c|c|c|c|c|}
\hline & \multicolumn{2}{|l|}{ East Asia land } & \multicolumn{2}{|c|}{ Maritime continent } \\
\hline & ARI and ACI & ARI & $\mathrm{ARI}$ and $\mathrm{ACI}$ & ARI \\
\hline Sulphate AOD at $0.55 \mu \mathrm{m}$ & 0.15 & 0.15 & -0.002 & -0.0004 \\
\hline Column integrated water vapor $\left(\mathrm{kg} \mathrm{m}^{-2}\right)$ & 0.35 & 0.20 & 1.10 & 0.19 \\
\hline High cloud cover $(\%)$ & -0.73 & 0.98 & 0.22 & 0.58 \\
\hline Medium cloud cover $(\%)$ & -0.57 & 0.27 & 0.36 & 0.04 \\
\hline Low cloud cover $(\%)$ & 0.80 & 1.47 & 0.44 & 0.23 \\
\hline Surface latent heat $\left(\mathrm{W} \mathrm{m}^{-2}\right)$ & 1.58 & 1.03 & 0.16 & 0.11 \\
\hline Surface sensible heat $\left(\mathrm{W} \mathrm{m}^{-2}\right)$ & 1.80 & 2.22 & -0.06 & 0.07 \\
\hline Surface total heat flux $\left(\mathrm{W} \mathrm{m}^{-2}\right)$ & -0.29 & -0.49 & 0.16 & -0.18 \\
\hline SAT $\left({ }^{\circ} \mathrm{C}\right)$ & -0.003 & -0.24 & 0.14 & 0.03 \\
\hline$\left(\mathrm{T}_{\mathrm{s}}-\mathrm{T}_{\mathrm{a}}\right)\left({ }^{\circ} \mathrm{C}\right)$ & -0.05 & -0.06 & 0.01 & -0.01 \\
\hline Precipitation $\left(\mathrm{mm} \mathrm{day}{ }^{-1}\right)$ & -0.18 & 0.18 & 0.35 & 0.02 \\
\hline \multirow[t]{2}{*}{ Omega at $500 \mathrm{hPa}\left(\mathrm{Pa} \mathrm{s}^{-1}\right)$} & 0.002 & -0.002 & -0.003 & 0.0002 \\
\hline & SW, LW & SW, LW & SW, LW & SW, LW \\
\hline TOA $\left(\mathrm{W} \mathrm{m}^{-2}\right)$ & $-2.56,-0.90$ & $-3.20,1.37$ & $-0.88,1.89$ & $-0.64,0.55$ \\
\hline TOA clear sky $\left(\mathrm{W} \mathrm{m}^{-2}\right)$ & $-3.65,0.23$ & $-3.77,0.82$ & $0.12,1.13$ & $0.01,0.15$ \\
\hline Cloud radiative effect (CRE) $\left(\mathrm{W} \mathrm{m}^{-2}\right)$ & $1.09,-1.13$ & $0.57,0.55$ & $-1.00,0.76$ & $-0.65,0.40$ \\
\hline Surface $\left(\mathrm{W} \mathrm{m}^{-2}\right)$ & $-5.04,1.36$ & $-5.73,1.99$ & $-1.30,1.35$ & $-0.73,0.37$ \\
\hline Surface clear sky $\left(\mathrm{W} \mathrm{m}^{-2}\right)$ & $-6.37,1.66$ & $-6.47,1.62$ & $-0.33,1.32$ & $-0.07,0.24$ \\
\hline Atm: TOA-Surface $\left(\mathrm{W} \mathrm{m}^{-2}\right)$ & $2.48,-2.26$ & $2.53,-0.62$ & $0.42,0.54$ & $0.10,0.18$ \\
\hline Atm: TOA-Surface clear sky $\left(\mathrm{W} \mathrm{m}^{-2}\right)$ & $2.72,-1.43$ & $2.70,-0.80$ & $0.46,-0.20$ & $0.09,-0.09$ \\
\hline
\end{tabular}

Radiation and fluxes are positive downwards aerosol in the 2000s relative to the 1970s (Lau et al. 2006; Meehl et al. 2008; Cazorla et al. 2013; Ocko et al. 2014). The changes of temperature in the lower and upper troposphere correspond an enhancement of East Asian subtropical westerly jet, an important component of East Asian summer monsoon circulation (Wang et al. 2017b), and weak southward displacement of the westerly jet in the lower and middle troposphere in both the East Asian and the western North Pacific sectors (Fig. 5e, f). This weak southward displacement of the westerly jet is shown to play a role in aerosol induced precipitation decreases over northern China (e.g., Yan et al. 2014; Wang et al. 2017b). The changes in local Hadley circulation are consistent with Ocko et al. (2014) who showed $\mathrm{SO}_{4}$ cooling in the $\mathrm{NH}$ induces an anomalous Hadley cell that rises in the Southern Hemisphere $(\mathrm{SH})$ and sinks in the NH. Our results further suggest that recent increased Asian AA emissions had a similar role in altering the local Hadley cell, causing anomalous ascents over the tropics and anomalous descents in subtropics across both East Asian and western Pacific sectors.

The most significant changes in surface air temperature are the warming over the Maritime continent (MC) and weak cooling further north over the WNP (Fig. 6a), consistent with the changes in SSTs shown in Fig. 4h. The warm temperature anomalies over the MC are associated with an anomalous cyclonic circulation locally, indicating the role of warm SSTs on the atmospheric circulation. In addition, there is anomalous anticyclonic circulation over the WNP (Fig. 6b) and anomalous descent through local Hadley circulation changes related to warming over the MC and weak cooling over the WNP (Fig. 5d). These circulation changes lead to anomalous moisture transport divergence over large land areas of East Asia and over the WNP, and anomalous moisture convergence over the MC (Fig. 6c). These changes in moisture flux are predominantly due to dynamical transport related to circulation changes (Fig. 6e). Thermodynamic transport related to changes in humidity is weak (Fig. 6f). The changes in dynamical moisture transport lead to a decrease in precipitation $\left(\sim 0.2-0.8 \mathrm{~mm}^{-1}\right.$ day $\left.^{-1}\right)$ over a large land area of East Asia, especially northern China, and over the WNP, and an increase in precipitation over the MC and the tropical Indian Ocean (Fig. 6d), indicating a southward shift of Intertropical Convergence Zone (ITCZ) and precipitation belt in the Asian and western Pacific sectors.

A southward shift of ITCZ and precipitation belt has been observed throughout the latter half of the twentieth century (e.g., Hwang et al. 2013; Allen et al. 2015; Voigt et al. 2017; Chung and Soden 2017) while precipitation changes over East Asia were characterized by enhanced precipitation over the middle and lower reaches of the Yangtze River valley and over southern China, and suppressed precipitation over northern China (Wang et al. 2013; Zhang et al. 2017; Tian et al. 2018). The shift of ITCZ has been linked to changes in the cross-equatorial energy transport driven 
by the interhemispheric contrast in sea surface temperatures (SSTs) resulted from changes in anthropogenic aerosols (e.g., Hwang et al. 2013; Allen et al. 2015; Voigt et al. 2017; Chung and Soden 2017) and decreased precipitation over northern China was attributed to increases in anthropogenic aerosols (Wang et al. 2013; Dong et al. 2016; Zhang et al. 2017; Tian et al. 2018). Results in this study suggest an important role of increased aerosol emissions over Asia on the southward shift of the Pacific ITCZ and precipitation belt during the latter half of the twentieth century. Importantly, the results also indicate that the ocean warming over the MC, and associated diabatic heating through enhanced deep convection, are important for the circulation and precipitation response over East Asia to increased Asian AA emissions.

Surface air temperature (SAT) changes are weak over a large land area in East Asia, (Fig. 6a) despite large decreases in clear sky SW radiation due to increases in AA emissions. These SAT changes over Asia in response to Asian emission changes reflect a balance between the direct impact of the increased emissions, inducing local cooling through both ARI and ACI (Fig. 4a, b), and the land surface and cloud feedbacks associated with reduced precipitation and cloud cover (Fig. 4c, d, g). The drying of soil and reduced cloud cover associated with reduced precipitation tend to warm the land surface through reduced evaporative cooling and positive anomalies of SW CRE, and therefore provide negative feedbacks on SAT change induced by increased aerosols (Fig. 4d, g; Table 2).

\subsection{Sea surface temperature response in pre-monsoon seasons}

The most important changes in boreal summer over ocean in response to increased Asian AA emissions are the warming over the MC and weak cooling over the WNP (Fig. 4h). Part of these changes is related to the processes highlighted above in boreal summer, and part is due to forced changes prior to boreal summer, due to large ocean memory. Illustrated in Fig. 7 are changes of CDNC, CDER and AOD in boreal winter (December-February: DJF) and spring (March-May: MAM). The changes in CDNC, CDER and AOD show significant seasonal variations in both magnitude and spatial distribution in comparison with changes shown in boreal summer (Fig. 3). Large significant increases in CDNC and AOD, and decreases in CDER, occur over East Asia, South and southeast Asia, and also over the western Indian Ocean in boreal winter (Fig. 7a-c), indicating transport of Asian aerosols by prevailing winds (e.g., Wang 2006). Accompanied by increased westerlies in boreal spring over the western tropical Pacific are downstream extension of changes in CDNC, CDER, and AOD over emission regions to the WNP (Fig. 7d-f). These seasonal variations are predominantly due to different transports related to seasonal variation of local circulation and precipitation (e.g., Jiang et al. 2015) since seasonal variation of local AA emissions is weak.

Key variables over ocean in DJF, MAM, and JJA, which reveal the role of increased Asian AA on SSTs over the WNP and tropical Ocean are illustrated in Fig. 8. There are decreases in clear sky SW (2-4 $\mathrm{W} \mathrm{m}^{-2}$ ) over the Arabian Sea, Bay of Bengal and along the coastal oceanic regions around East Asia in DJF (Fig. 8a) and large decreases over the WNP downstream of East Asia in MAM (Fig. 8b), consistent with seasonal increased AOD over these regions (Fig. 7c, f). The changes in SW CRE, which are partly due to aerosol induced changes in cloud-microphysics and partly due to cloud cover changes associated with AA induced changes in atmospheric circulation, show a complex pattern. The main features are negative values of SW CRE over the Arabian Sea, Bay of Bengal, and over the subtropical western Pacific, associated with local increases in CDNC and decreases in CDER (Fig. 7a, b). The negative SW CRE over the Maritime continent is mainly associated with increased cloud cover accompanying the increased water vapour (Fig. 8g, h) and enhanced convection (not shown) where changes in CDNC, CDER, and AOD are weak (Fig. 7). These results indicate that Asian AA changes induce the atmospheric circulation changes, which in turn induce additional cloud changes. Associated with these changes in surface radiation and turbulent heat fluxes are the anomalous cooling over the WNP and weak warming over the tropical regions of the Indian Ocean and the WNP in both DJF and MAM (Fig. 8j, k). These SST changes result in an anomalous meridional SST gradient in the western Pacific. This gradient is further amplified in JJA (Fig. 8j) through positive feedbacks over the MC, highlighted in Fig. 4. The increases of surface SW by $2-8 \mathrm{~W} \mathrm{~m}^{-2}$ over the WNP in JJA are the result of decreased cloud cover (Fig. 4c), associated with anomalous anticyclonic circulation (Fig. 6b) and a decrease in atmospheric water vapor content (Fig. 8i), which tends to dampen the cold SST anomalies induced by Asian aerosol increases in boreal winter and spring (Fig. 8j, k). Therefore, SST changes in JJA over adjacent ocean around East Asia (Fig. 81) are the combination of response to aerosol changes in pre-monsoon seasons and of simultaneous response in JJA to increased Asian AA emissions.

\subsection{The role of ARI in the EASM and precipitation responses to Asian AA changes}

Simulated changes of some key variables of the surface energy balance, sectorially averaged temperature and vertical velocity, and climate around East Asia in response to the Asian AA emission increase from the 1970s to 2000s, considering ARI only, are shown in Figs. 9 and 10. 
(a) CDNC in DJF (Asia AA)

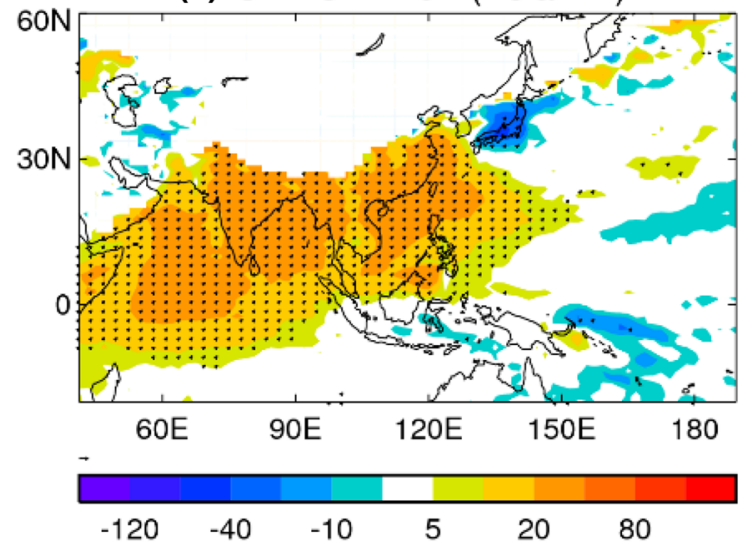

(b) CDER in DJF (Asia AA)

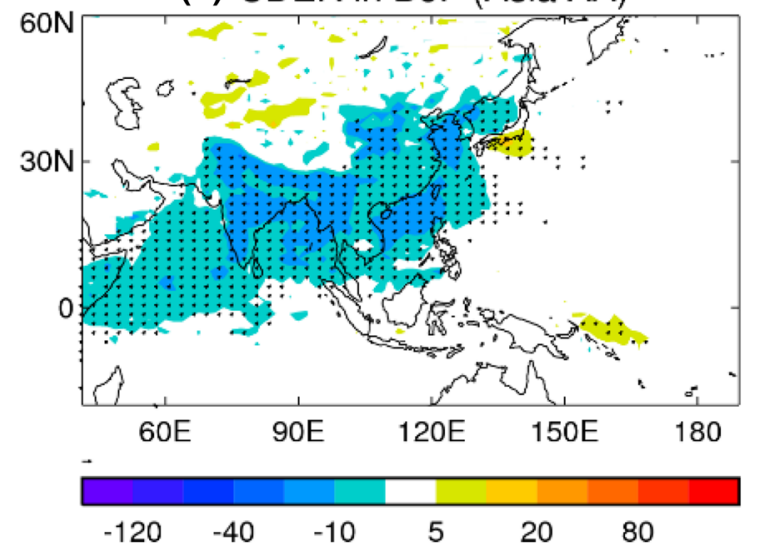

(c) AOD at 0.55 um in DJF (Asia AA)

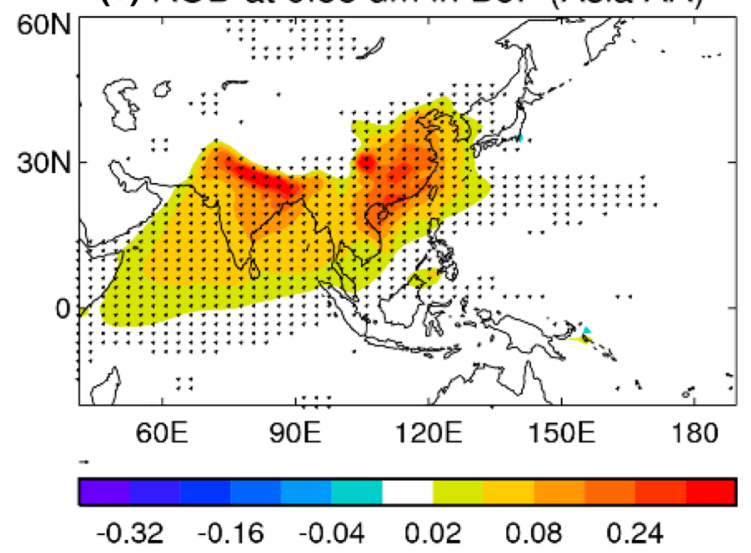

Fig. 7 The spatial patterns of simulated changes in (left) DJF, and (right) MAM for (a, d) cloud droplet number concentration (CDNC), $(\mathbf{b}, \mathbf{e})$ cloud droplet effective radius (CDER), and (c, f) AOD at $0.55 \mu \mathrm{m}$ in response to changes in Asian AA precursor emissions

When considering ARI only, the model simulated changes in clear sky surface shortwave radiation (Fig. 9a) are similar to that induced by including both ARI and ACI (Fig. 4a; Table 2), as expected. The changes in surface (d) CDNC in MAM (Asia AA)

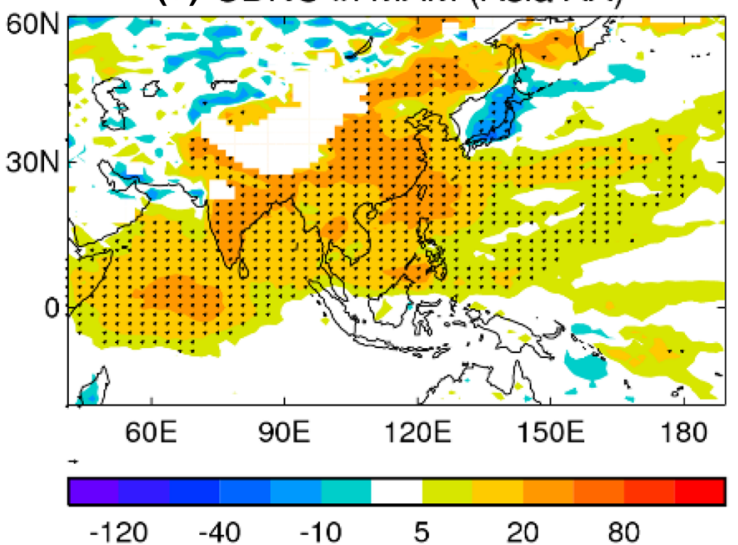

(e) CDER in MAM (Asia AA)

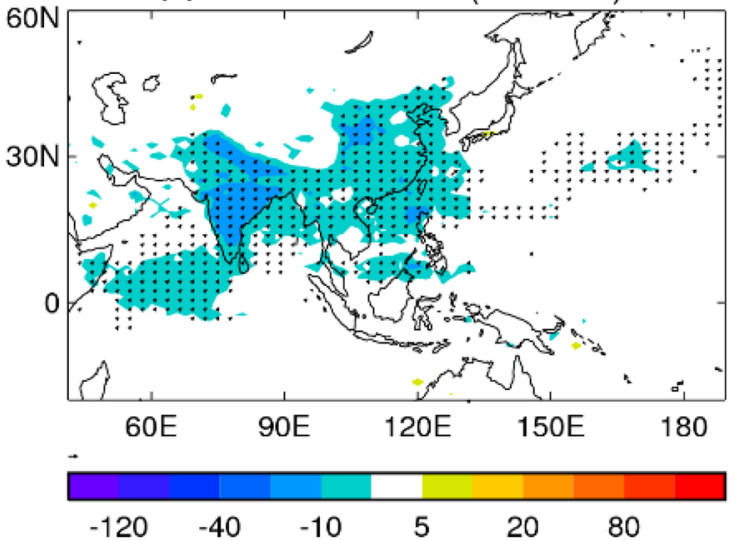

(f) AOD at 0.55 um in MAM (Asia AA)

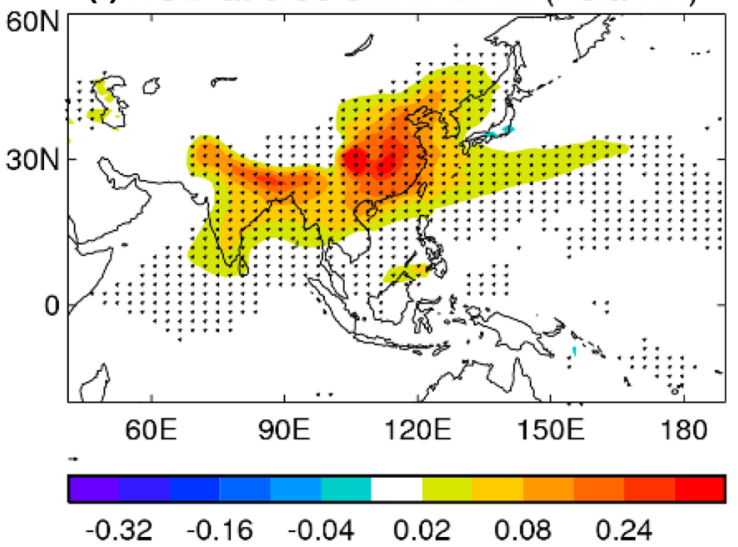

(E1-E2). Changes in CDCN and CDER are percentage changes relative to the experiment E1. Black dots highlight regions where the changes are statistically significant at the $10 \%$ level using a two-tailed Student's t-test

SW radiation over East Asia are slightly stronger than changes in clear sky SW (Fig. 9a, b), implying a weak positive cloud feedback on reduced SW radiation (negative SW CRE) over East Asia, related to the increase in 

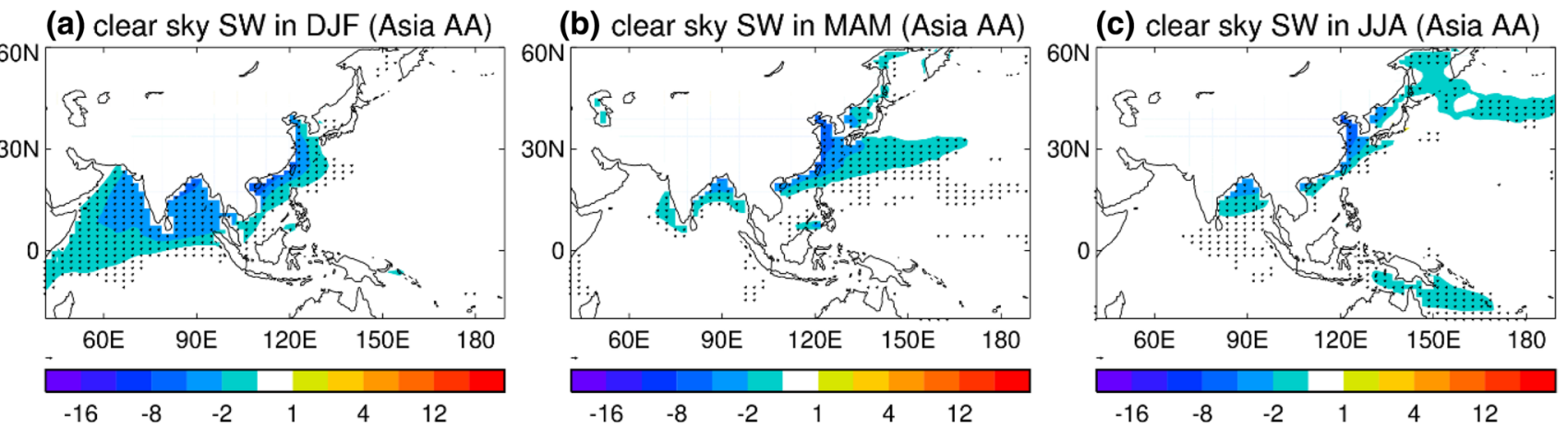

(d) CRE SW in DJF (Asia AA)

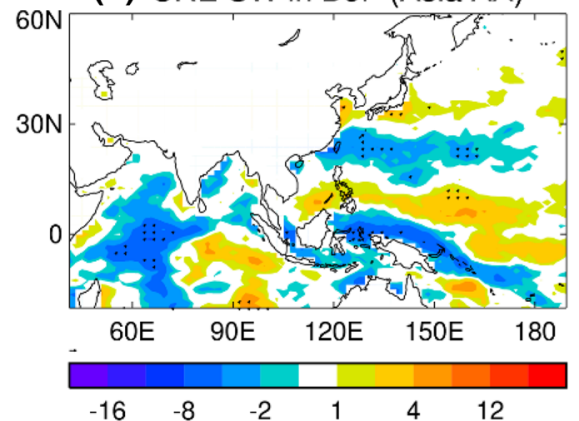

(e) CRE SW in MAM (Asia AA)

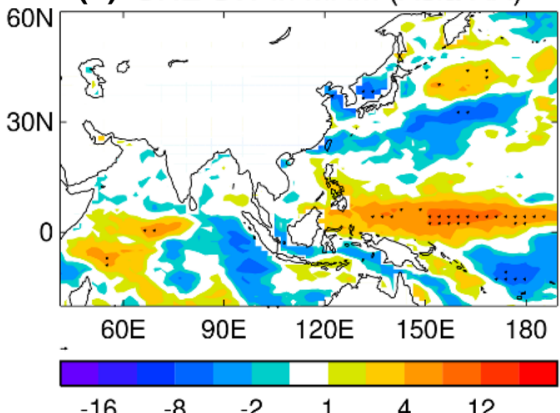

(f) CRE SW in JJA (Asia AA)

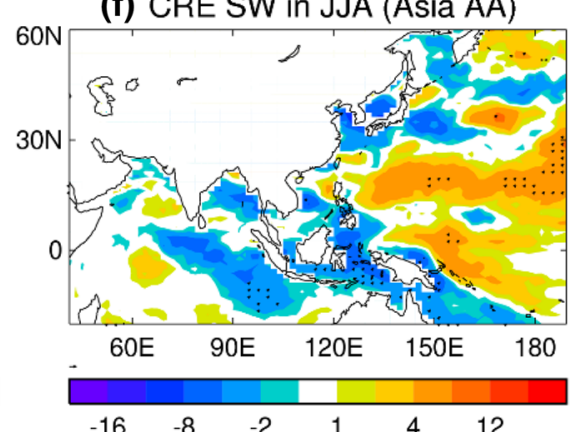

(g) Water vapor in DJF (Asia AA)

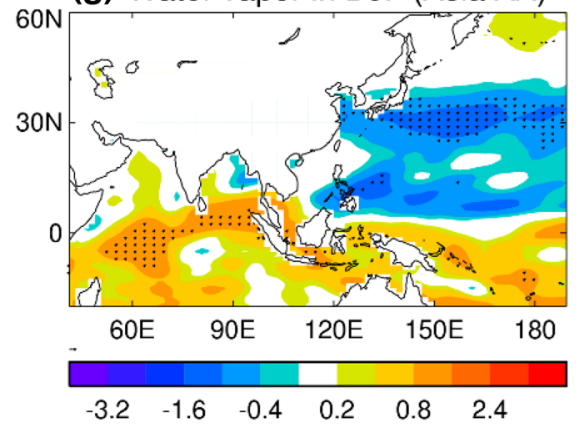

(h) Water vapor in MAM (Asia AA)

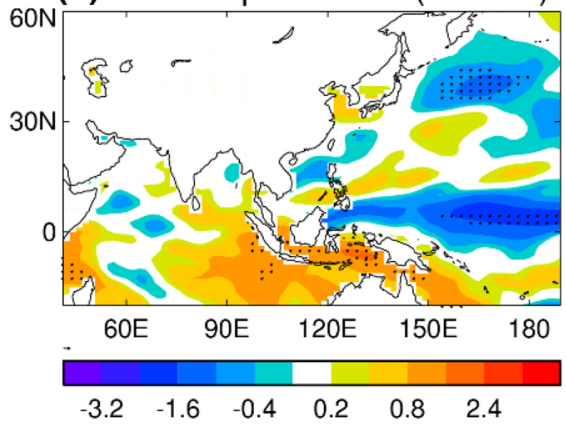

(i) Water vapor in JJA (Asia AA)

(j) SST in DJF (Asia AA)

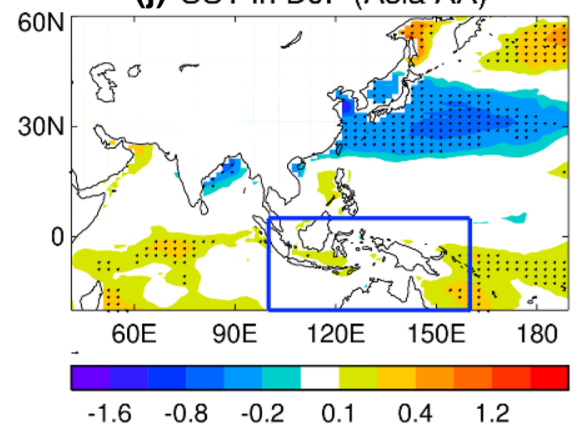

(k) SST in MAM (Asia AA)
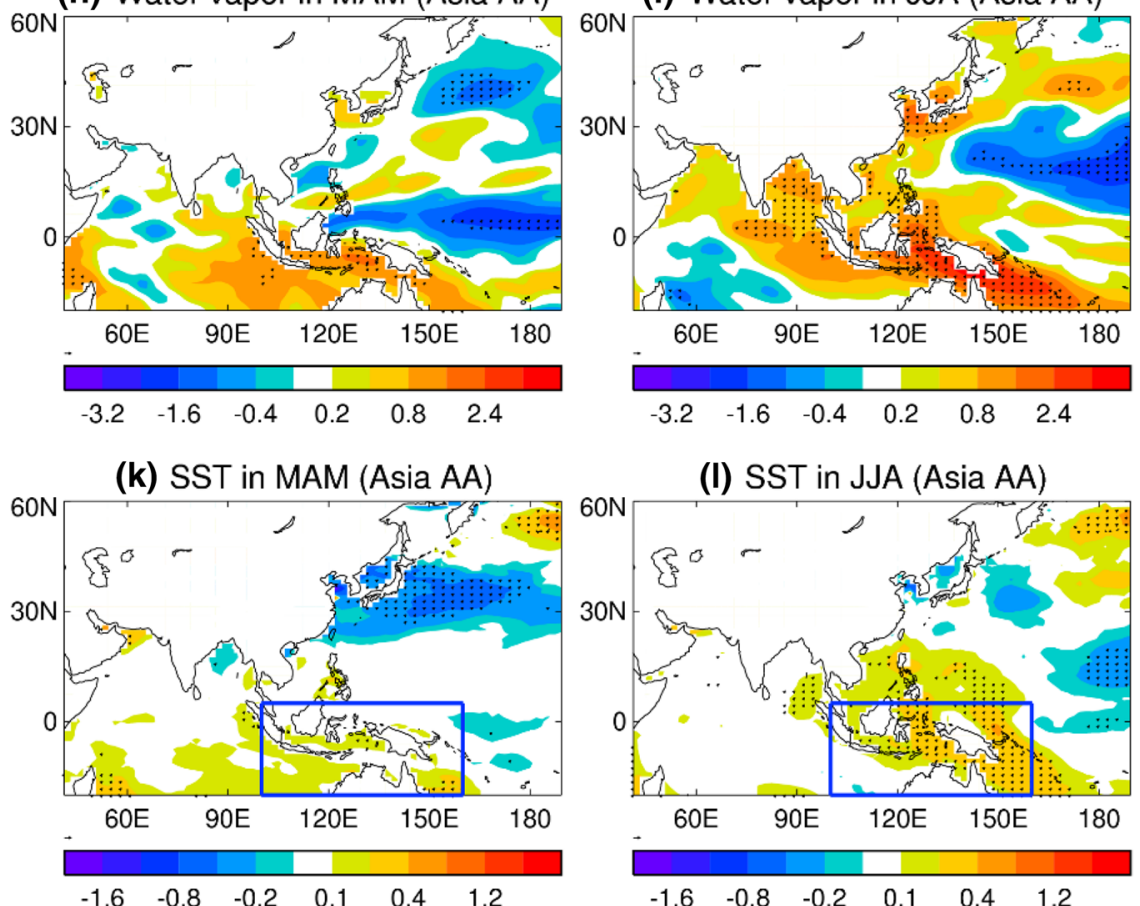

(I) SST in JJA (Asia AA)

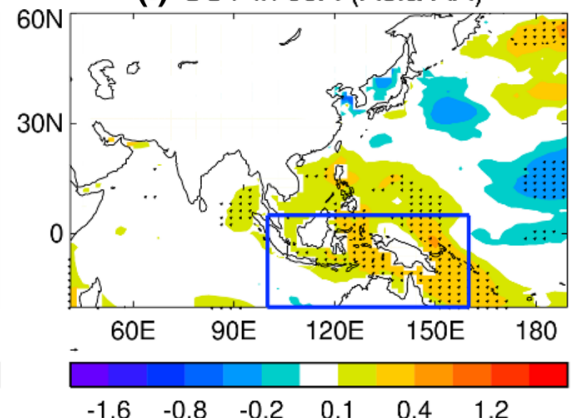

Fig. 8 Spatial patterns of changes in (a-c) surface clear sky SW (W $\left.\mathrm{m}^{-2}\right),(\mathbf{d}-\mathbf{f})$ CRE SW $\left(\mathrm{W} \mathrm{m}^{-2}\right),(\mathbf{g}-\mathbf{i})$ vertically integrated water vapor $\left(\mathrm{kg} \mathrm{m}^{-2}\right),(\mathbf{j}-\mathbf{l}) \mathrm{SST}\left({ }^{\circ} \mathrm{C}\right)$ in response to changes in Asian AA precursor emissions through both ARI and ACI in DJF (left panel), MAM

cloud cover (Fig. 9c, d). The weak changes in surface SW over South Asia are the result of a decrease in cloud there, which induces positive SW CRE (Fig. 8c, d). The positive anomalies of surface LW and surface turbulent heat flux (middle panel), and JJA (right panel). Black dots highlight regions where the changes are statistically significant at the $10 \%$ level using a two-tailed Student's t-test

changes indicate decreased upward surface LW. This is a result of surface cooling and decreased upward turbulent heat flux, which is mainly related to the decrease in surface and surface air temperature gradient $\left(\mathrm{T}_{\mathrm{s}}-\mathrm{T}_{\mathrm{a}}\right.$, Table 2$)$, and 


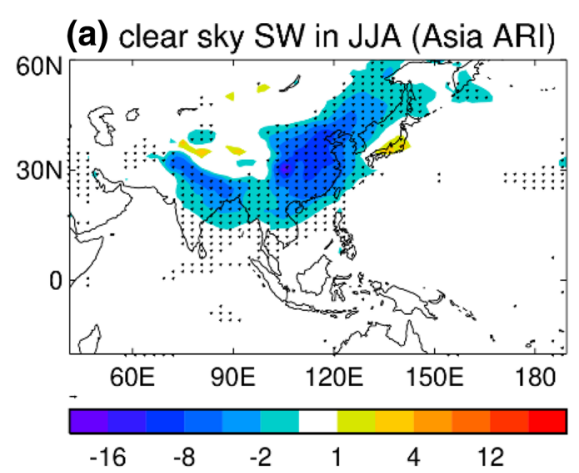

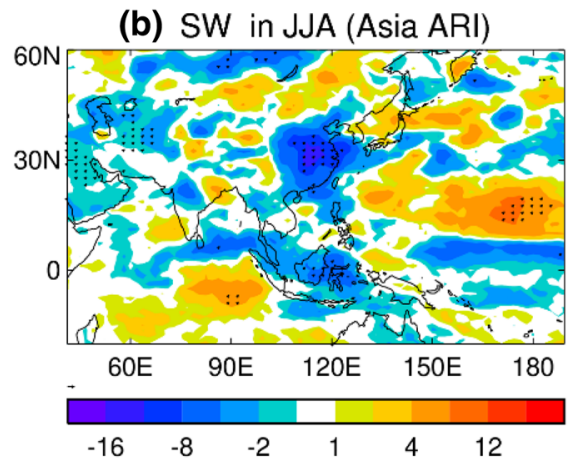

(c) total cloud in JJA (Asia ARI)

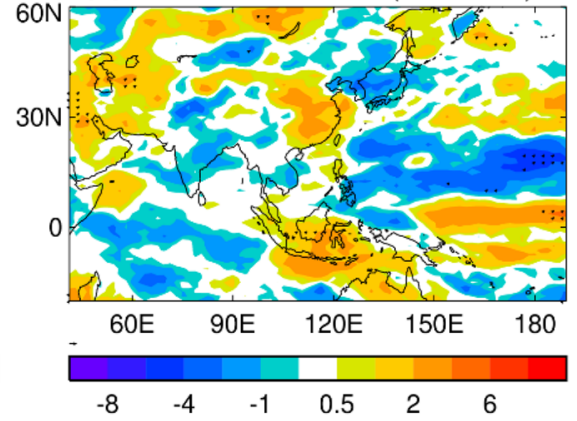

(f) LW in JJA (Asia ARI)
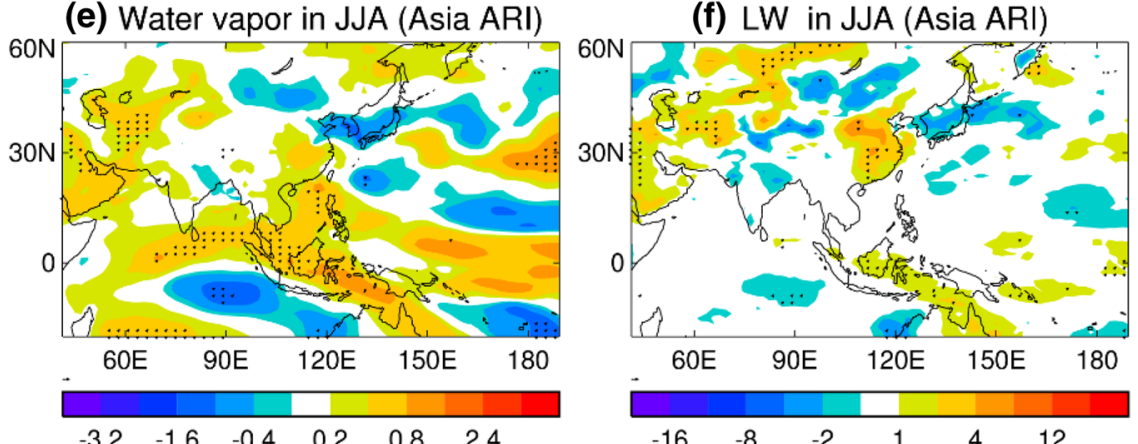

(g) LH \& SH in JJA (Asia ARI)

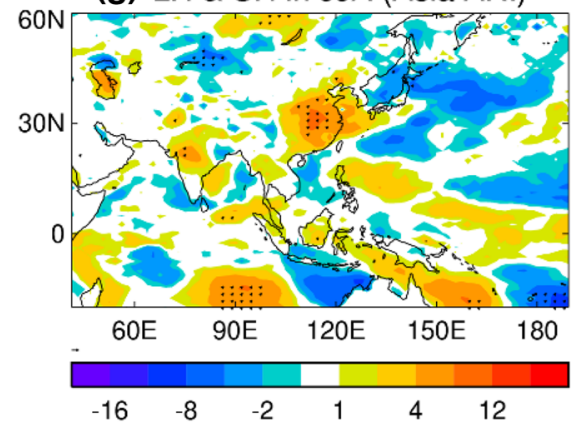

(h) surface temp in JJA (Asia ARI)

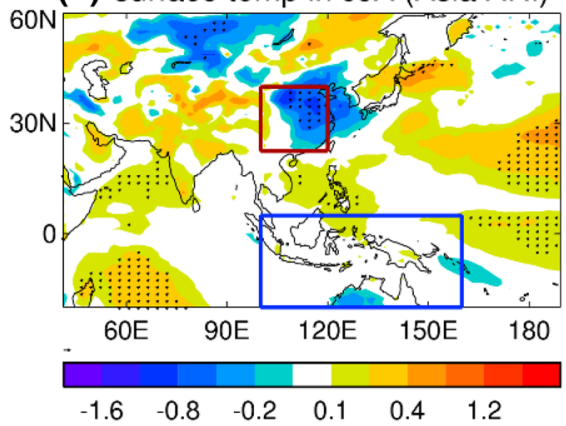

Fig. 9 Spatial patterns of simulated changes in JJA for some variables and surface energy components in response to changes in Asian AA precursor emissions through ARI (E1ARI-E2ARI). Radiation and fluxes are in $\mathrm{W} \mathrm{m}^{-2}$ and positive downwards. Cloud cover is in $\%$, and water vapor is in $\mathrm{kg} \mathrm{m}^{-2}$. Black dots highlight regions where the changes are statistically significant at the $10 \%$ level using a two-tailed Student's t-test

Over land in East Asia, there is anomalous ascent associated with cooling in the troposphere, indicating that this cooling is dynamically generated (Fig. 10a, c; Table 2). The anomalous ascent and increased precipitation over East Asia might be the result of the elevated heat pump effect of increased absorbing aerosols over Asia (Lau et al. 2006).

In contrast to the response to Asian AA emission increases when both ARI and ACI are included (Fig. 4), aerosol induced changes in SSTs over the MC and WNP through ARI only are generally weak, associated with weak responses in pre-monsoon seasons (not shown) and weak water vapor feedback in JJA (Fig. 9e, h; Table 2). Associated with weak SST changes over the MC and WNP indicating very weak changes in the local Hadley cell. 
(a) Tem (100E-120E) (Asia ARI) in JJA

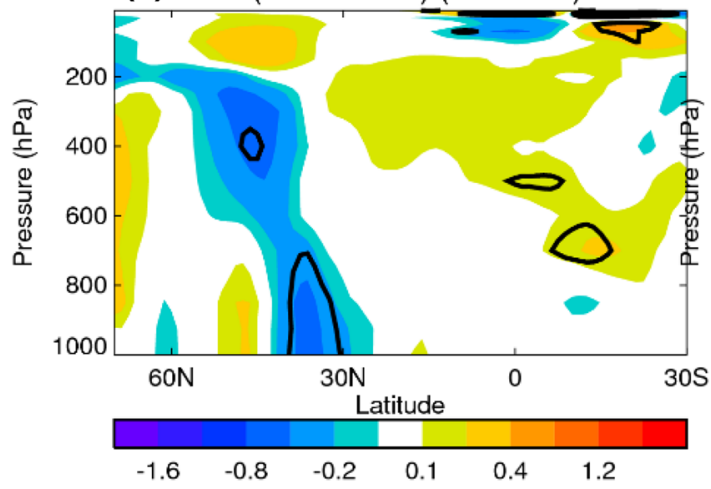

(c) Omega (100E-120E) (Asia ARI) in JJA

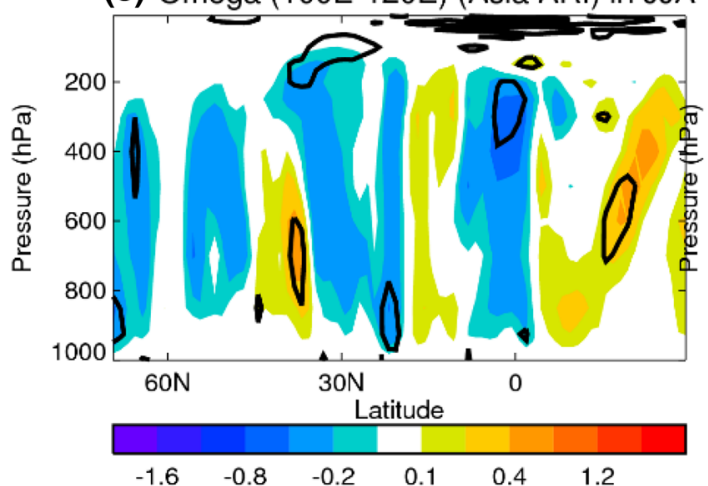

(e) JJA SAT (Asia ARI)

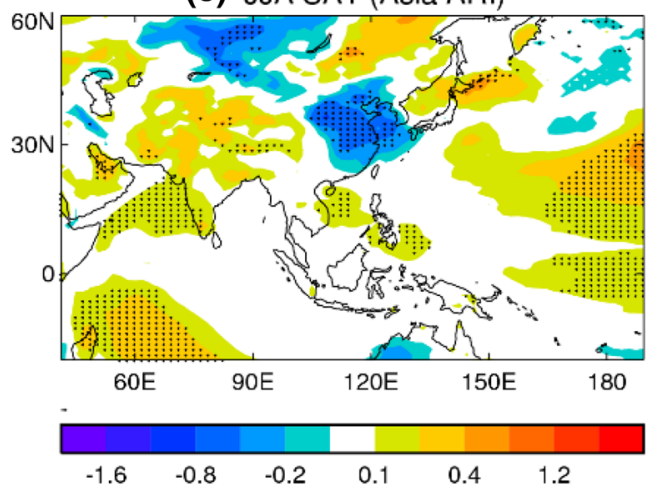

(g) JJA MC and transport (Asia ARI)

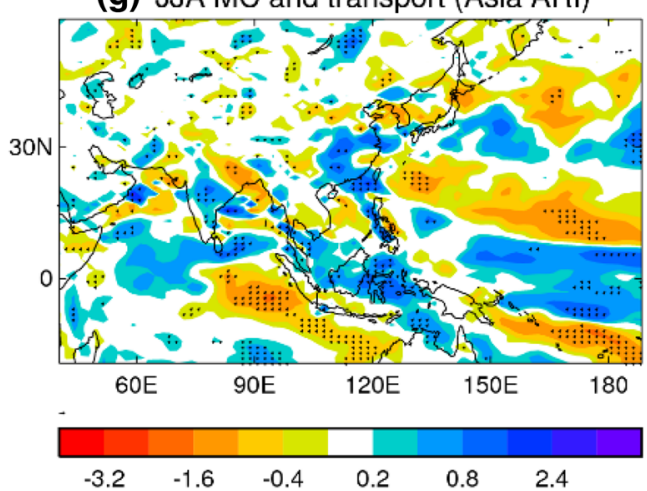

(b) Tem (120E-150E) (Asia ARI) in JJA

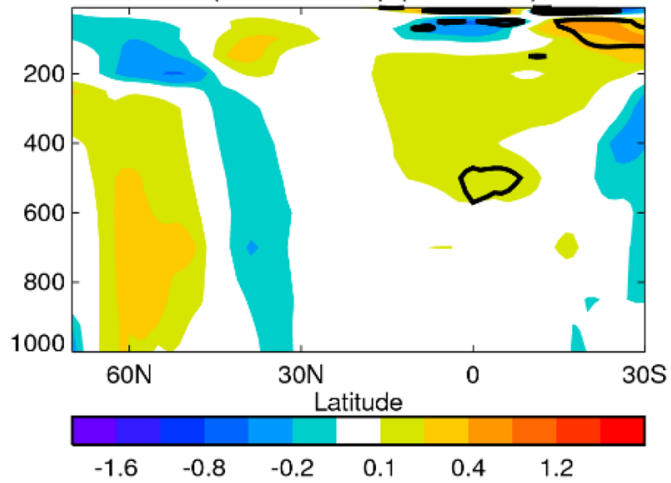

(d) Omega (120E-150E) (Asia ARI) in JJA

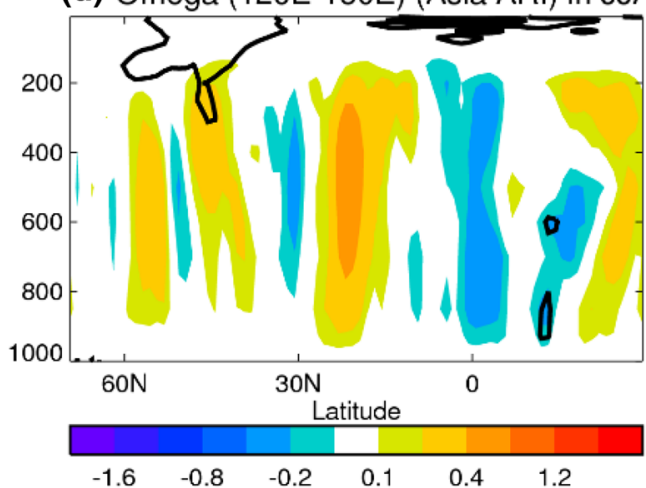

(f) JJA SLP and $850 \mathrm{hPa}$ wind (Asia ARI)

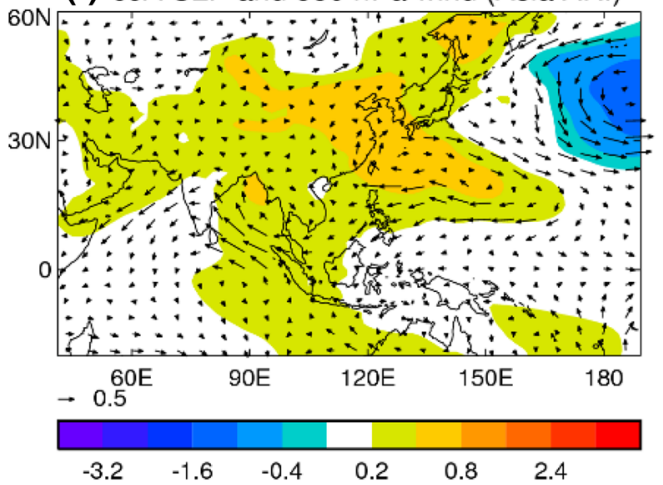

(h) JJA Precipitation change (Asia ARI)

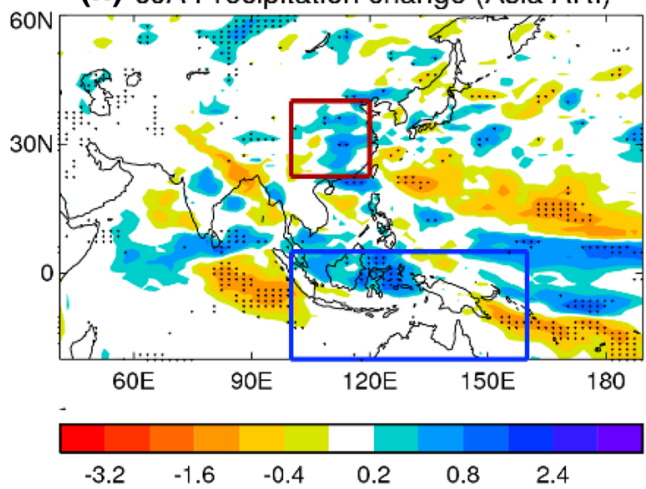


4Fig. 10 Simulated zonal averaged changes in (a, b) temperature $\left({ }^{\circ} \mathrm{C}\right),(\mathbf{c}, \mathbf{d})$ vertical velocity $\left(\mathrm{hPa} \times 10^{-2} \mathrm{~s}^{-1}\right)$ over East Asian sector $\left(100^{\circ} \mathrm{E}-120^{\circ} \mathrm{E}\right)$ and over the western Pacific sector $\left(120^{\circ} \mathrm{E}-150^{\circ} \mathrm{E}\right)$ and changes in e SAT $\left({ }^{\circ} \mathrm{C}\right)$, f SLP and $850 \mathrm{hPa}$ wind $\left(\mathrm{hPa}\right.$ and $\left.\mathrm{m} \mathrm{s}^{-1}\right)$, g vertically integrated moisture flux convergence $\left(\mathrm{kg} \mathrm{m}^{-2}\right.$ day $\left.^{-1}\right)$, and $\mathbf{h}$ precipitation $\left(\mathrm{mm} \mathrm{day}^{-1}\right)$ in response to changes in Asian AA precursor emissions through ARI (E1ARI-E2ARI). Black lines (a-d) and dots $(\mathbf{e}, \mathbf{g}, \mathbf{h})$ highlight regions where the changes are statistically significant at the $10 \%$ level using a two-tailed Student's t-test

are weak changes of low tropospheric circulation, vertically integrated moisture transport, and therefore precipitation (Fig. 10f, g, h). However, the SAT changes over East Asia show some significant cooling (Fig. 10e) since local negative feedbacks associated with changes in precipitation and cloud are relatively weak.

\subsection{The role of $\mathrm{ACl}$ in the EASM and precipitation responses to Asian AA changes}

The response to ACI alone is inferred from the difference between the full simulation, and one with just ARI. Changes of some key variables of the surface energy balance, sectorially averaged vertical velocity, and climate over East Asia induced by ACI in response to the Asian AA increase from 1970s to 2000s around East Asia are illustrated in Figs. 11 and 12. Without including ARI, changes in clear sky surface SW radiation are very weak (Fig. 11a). The main changes over land over East Asia are increased surface SW, predominantly due to positive SW CRE, associated with decreases in cloud cover (Fig. 11b-d), which tend to warm the land surface (Fig. 11h). Over the MC, it is increased water vapor and associated LW warming that are responsible for increased SSTs locally, while over the WNP decreased water vapor is associated with cooling. In addition to these simultaneous processes, the SST changes before boreal summer also play a role in the SST gradient changes between the tropics and the western North Pacific in boreal summer (not shown), similar to the total response over the tropical and subtropical ocean seen in Sect. 3.2. These results indicate that the warming over the MC, associated processes for this warming, and the cooling over the WNP in response to increases in Asian AA emissions are predominantly regulated by ACI.

Zonally averaged responses in vertical velocity indicate anomalous ascent in the tropics and descent over subtropics in both the East Asian and western Pacific sectors (Fig. 12a, b). All these changes are similar to the responses to Asian AA emission changes including both ARI and ACI (Fig. 6c, d). In many aspects, implied responses in SAT, low tropospheric circulation, vertically integrated moisture transport convergence, and precipitation, to changes in Asian AA emissions through ACI (Fig. 12c-f) are similar to those in the total response to
Asian AA changes (Fig. 6a-d). These are especially true over ocean around the $\mathrm{MC}$, indicating a dominant role of ACI in response to Asian AA increases over adjacent ocean around East Asia (Table 2).

\section{Role of ocean feedbacks over the Maritime continent}

In the previous section it has been demonstrated that increased Asian AA from 1970s to 2000s lead to changes in local Hadley circulation over both the East Asian and western Pacific sectors. These anomalous local circulations, characterized by anomalous ascent in the tropics and anomalous descent in northern subtropics, are associated with warming SSTs over the Maritime continent. These anomalous circulations are, in turn, responsible for the precipitation decreases over a large land area over East Asia. All the main features of changes in response to Asian AA emission increases are predominantly through $\mathrm{ACI}$, in which oceanic feedbacks over the MC play an important role. The responses to anomalous SSTs over the MC from a pair of AGCM experiments are illustrated in Fig. 13.

In response to Asain AA change induced SST anomalies over the MC, the most important features over both the East Asian and western Pacific sectors are anomalous ascent in the tropics and descent in northern subtropics (Fig. 13a, b). These changes in vertical motion bear a similarity to the local Hadley circulation changes in response to Asian AA increase (Fig. 5c, d) but with weaker magnitude (about 50\%) in the Asian sector. The local Hadley circulation changes are associated with anomalous high SLP over northern subtropics, and anomalous anticyclonic circulation over the WNP, similar in pattern to what was seen in the total responses to Asian AA changes, but weaker in magnitude. This weak magnitude of response to the imposed SST anomalies over the MC implies that other SST anomalies induced by increased Asian AA emissions might also have played a role in establishing the anomalous anticyclonic circulation over the WNP. In particular, the local cooling over the WNP has previously been shown to be an important driver of anomalous anticyclonic circulation over the WNP (e.g., Lu and Dong 2001). This anomalous local Hadley circulation and anomalous anticyclonic circulation over the WNP lead to increased moisture transport convergence over the $\mathrm{MC}$ and divergence over land in East Asia, and therefore changes in local precipitation (Fig. 13e, f). Therefore, AA induced SST feedbacks over the MC play an important role in changes in precipitation over East Asia in response to increases in Asian AA emissions in the coupled model, through their influence on the local Hadley circulation over the tropical and subtropical Pacific. The sensitivity of the local Hadley 

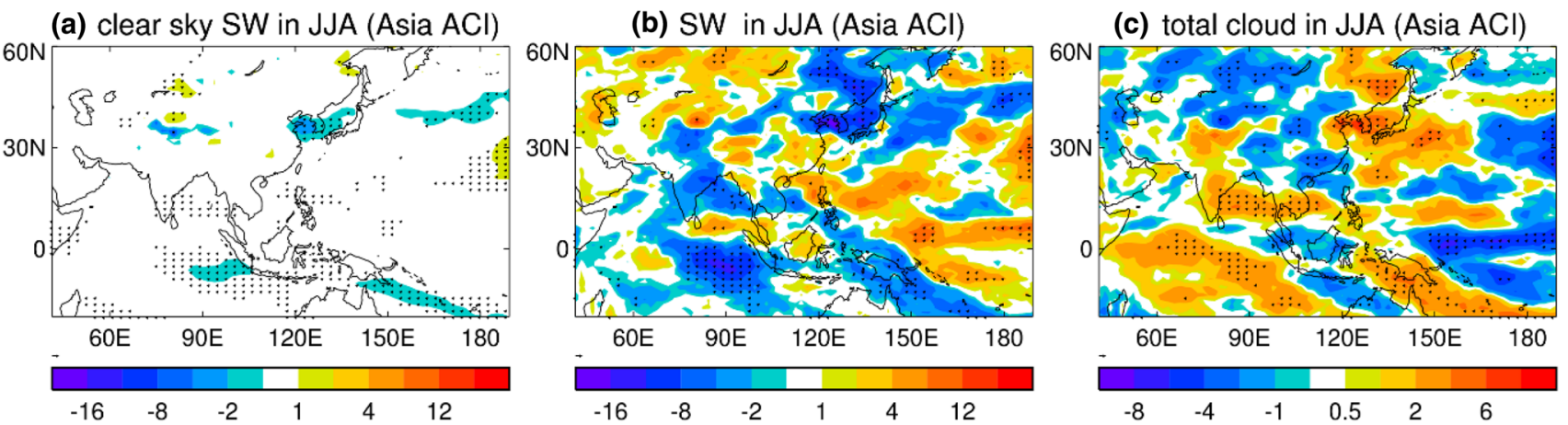

(d) CRE SW in JJA (Asia ACI)

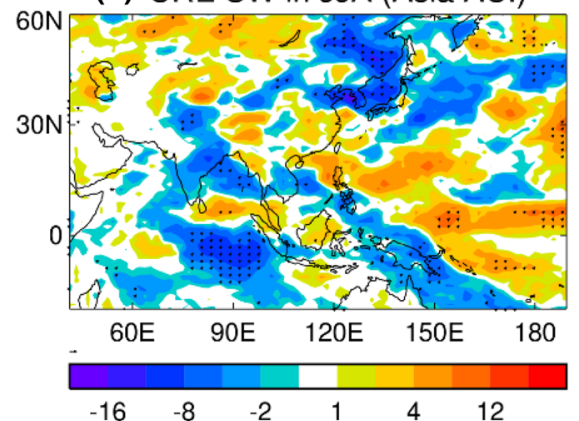

(e) Water vapor in JJA (Asia ACI)

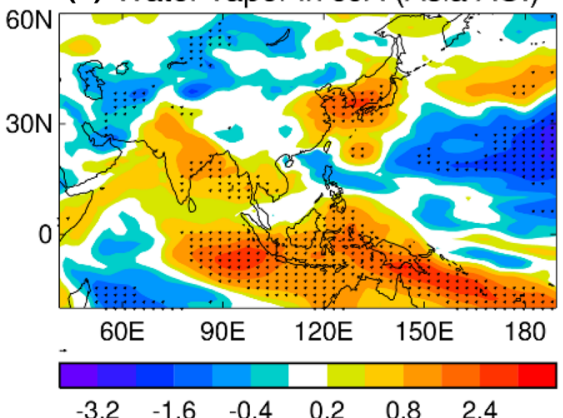

(f) LW in JJA (Asia ACI)

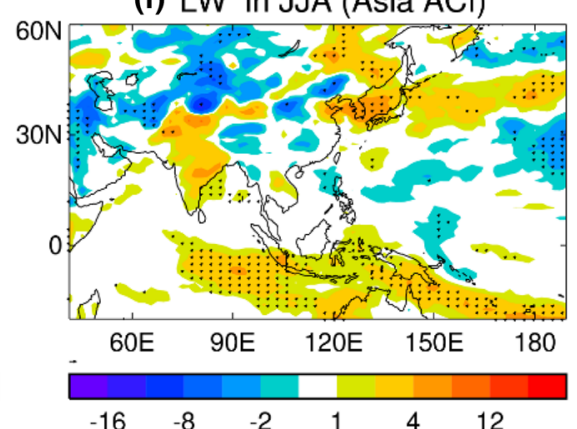

(g) LH \& SH in JJA (Asia ACl)

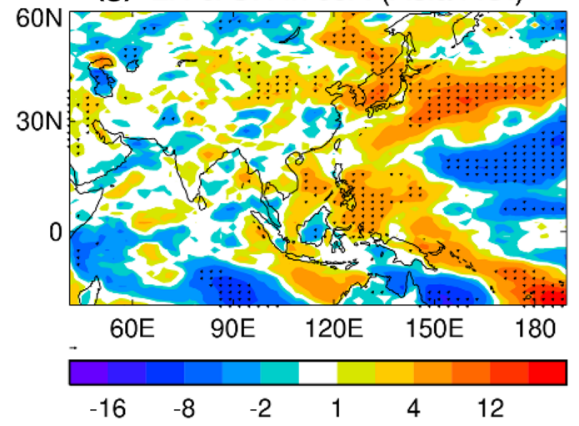

(h) surface temp in JJA (Asia ACl)

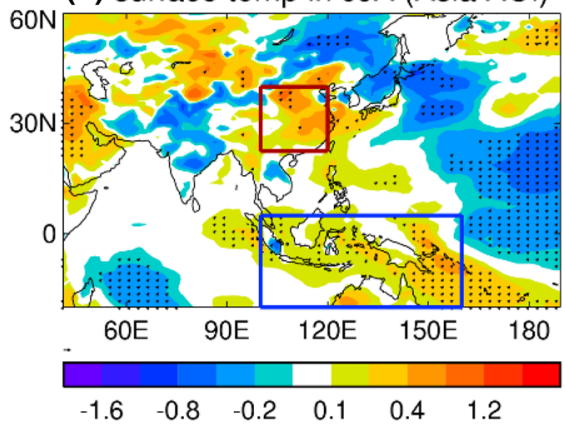

Fig. 11 Spatial patterns of implied changes in JJA for some variables and surface energy components in response to changes in Asian AA precursor emissions through ACI [(E1-E2)-(E1ARI-E2ARI)]. Radiation and fluxes are in $\mathrm{W} \mathrm{m}^{-2}$ and positive downwards. Cloud cover is in $\%$, and water vapor is in $\mathrm{kg} \mathrm{m}^{-2}$. Black dots highlight regions where the changes are statistically significant at the $10 \%$ level using a two-tailed Student's t-test

importance of ocean dynamical feedbacks, mainly initiated through aerosol-cloud interaction, in shaping the changes of the climate over East Asia. The major processes responsible for changes in the East Asian summer monsoon and precipitation in response to Asian AA emissions increases from 1970s to 1990s are summarized schematically in Fig. 14. The main findings are summarized as follows:

- Increased Asian AA emissions lead to localized increases in cloud droplet number concentration (CDNC), decreases in cloud droplet effective radius (CDER) and increases in aerosol optical depth (AOD). These changes have clear seasonal variations related to prevailing climatological winds. 
(a) Omega (100E-120E) (Asia ACI) in JJA

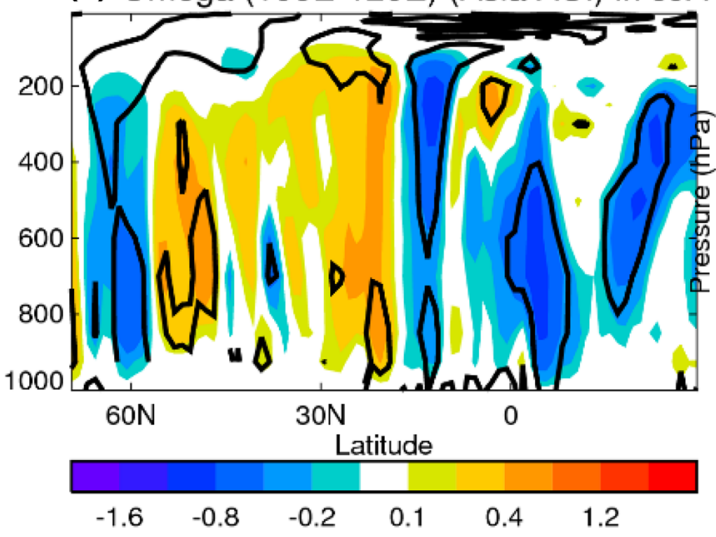

(c) JJA SAT (Asia ACI)

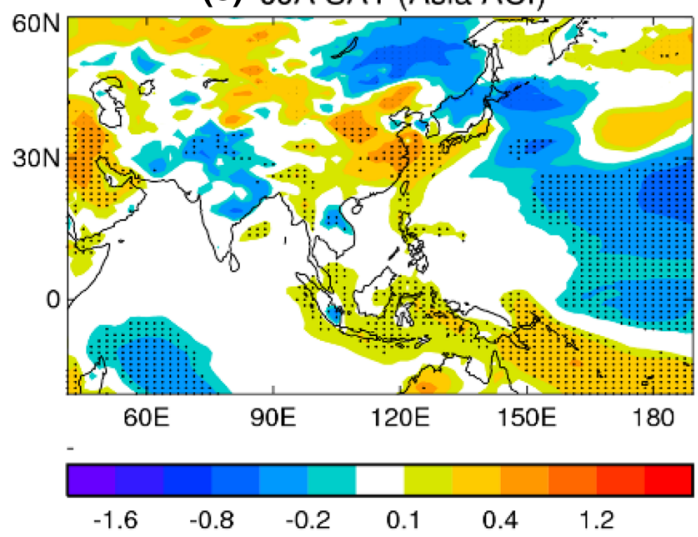

(e) JJA MC and transport (Asia ACI)

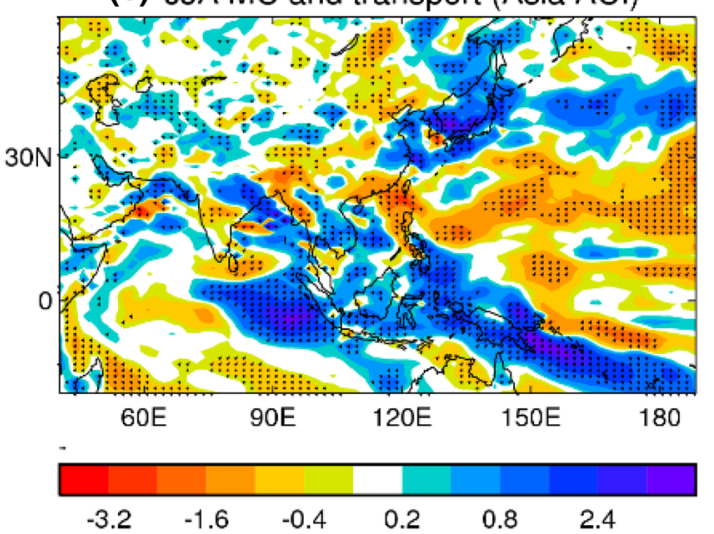

Fig. 12 Implied changes in (a, b) vertical velocity $\left(\mathrm{hPa} \times 10^{-2} \mathrm{~s}^{-1}\right)$ over East Asian sector $\left(100^{\circ} \mathrm{E}-120^{\circ} \mathrm{E}\right)$ and over the western Pacific sector $\left(120^{\circ} \mathrm{E}-150^{\circ} \mathrm{E}\right)$ and changes in c SAT $\left({ }^{\circ} \mathrm{C}\right)$, d SLP and $850 \mathrm{hPa}$ wind ( $\mathrm{hPa}$ and $\mathrm{m} \mathrm{s}^{-1}$ ), e vertically integrated moisture flux convergence $\left(\mathrm{kg} \mathrm{m}^{-2}\right.$ day $\left.^{-1}\right)$, and $\mathbf{f}$ precipitation $\left(\mathrm{mm} \mathrm{day}^{-1}\right)$ in JJA in (b) Omega (120E-150E) (Asia ACl) in JJA

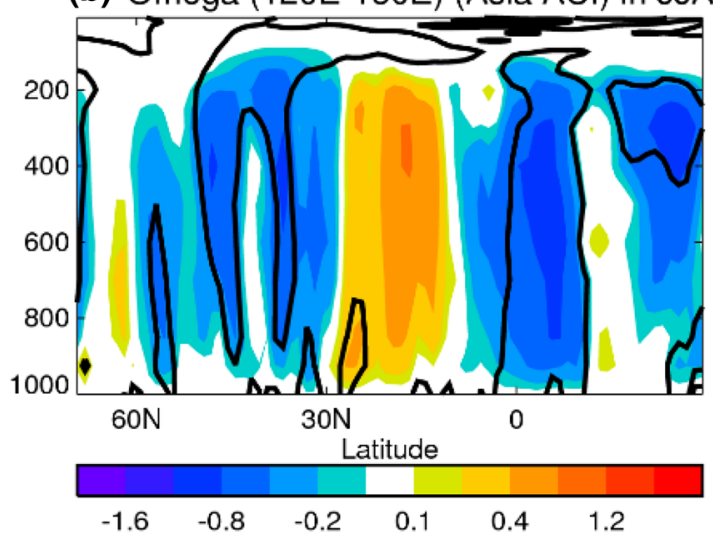

(d) JJA SLP and $850 \mathrm{hPa}$ wind (Asia ACl)

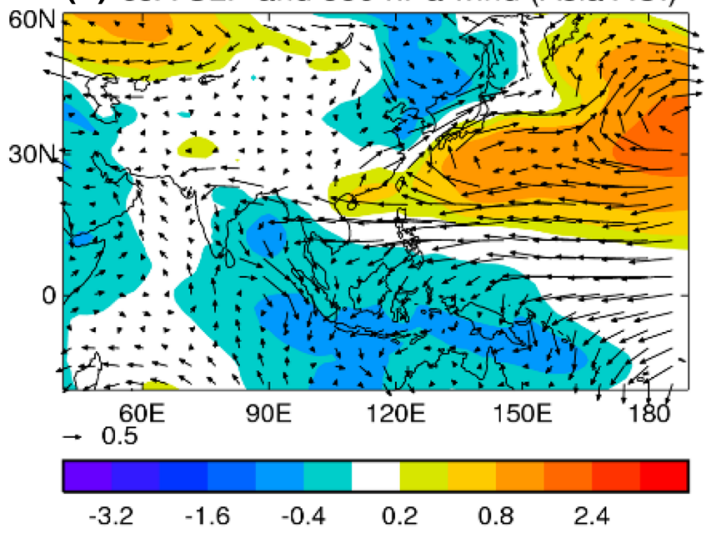

(f) JJA Precipitation change (Asia ACl)

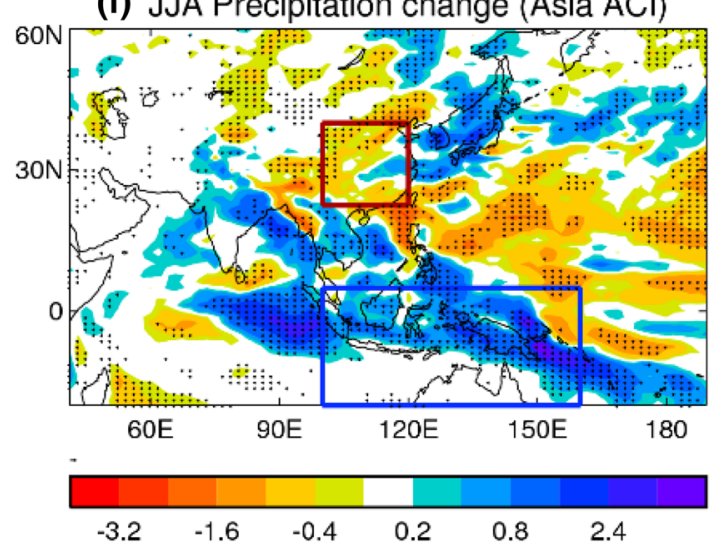

response to changes in Asian AA precursor emissions through ACI [(E1-E2)-(E1ARI-E2ARI)].). Black lines (a, b) and dots (c, e, f) highlight regions where the changes are statistically significant at the $10 \%$ level using a two-tailed Student's t-test 


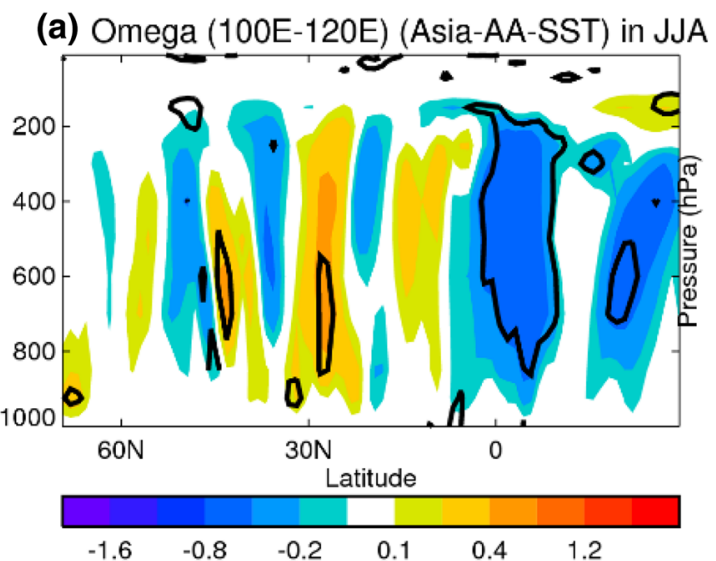

(c) JJA SAT (Asia-AA-SST)

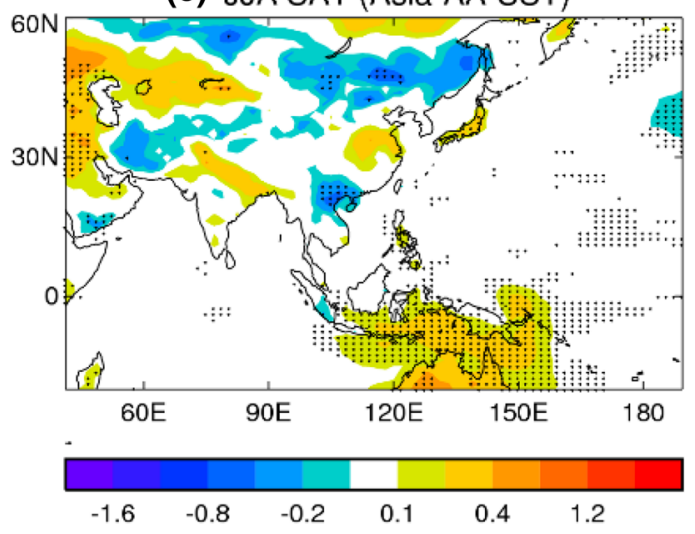

(e) JJA MC and transport (Asia-AA-SST)

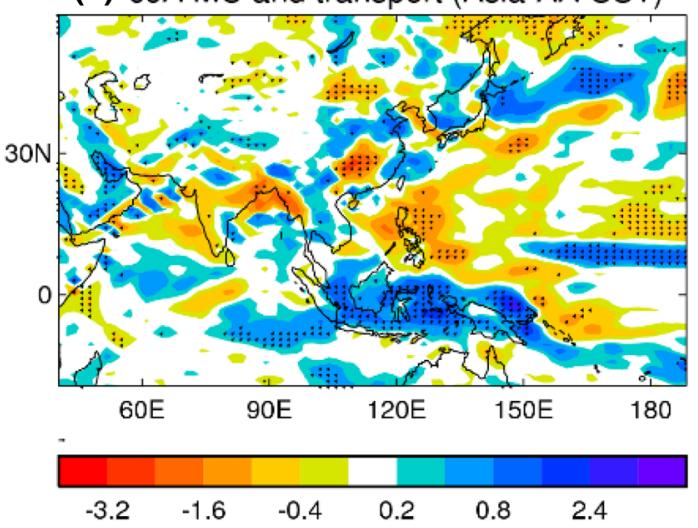

Fig. 13 Simulated zonal averaged changes in $(\mathbf{a}, \mathbf{b})$ vertical velocity $\left(\mathrm{hPa} \times 10^{-2} \mathrm{~s}^{-1}\right)$ over East Asian sector $\left(100^{\circ} \mathrm{E}-120^{\circ} \mathrm{E}\right)$ and over the western Pacific sector $\left(120^{\circ} \mathrm{E}-150^{\circ} \mathrm{E}\right)$ and changes in c SAT $\left({ }^{\circ} \mathrm{C}\right)$, d SLP and $850 \mathrm{hPa}$ wind ( $\mathrm{hPa}$ and $\mathrm{m} \mathrm{s}^{-1}$ ), e vertically integrated moisture flux convergence $\left(\mathrm{kg} \mathrm{m}^{-2} \mathrm{day}^{-1}\right)$, and $\mathbf{f}$ precipitation $\left(\mathrm{mm} \mathrm{day}{ }^{-1}\right)$

- Increased Asian AA emissions lead to weak cooling over land in East Asia. The weak SAT changes over Asia reflect a balance between the direct impact of the changes in AA, inducing local cooling through both ARI and ACI, and the land surface and cloud feedbacks (b) Omega (120E-150E) (Asia-AA-SST) in JJA

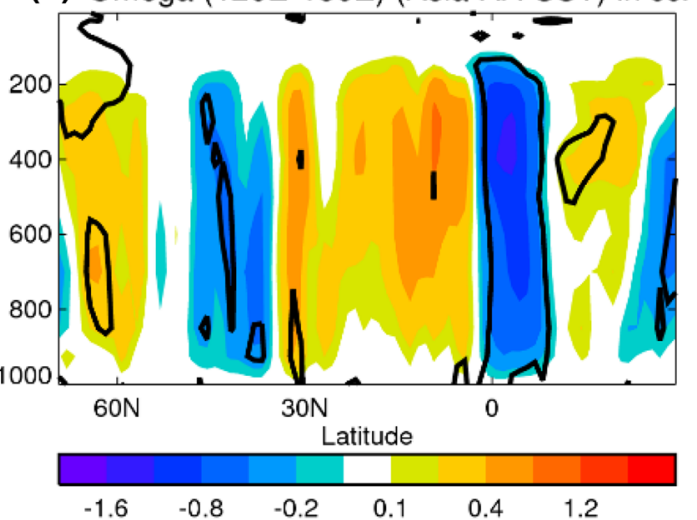

(d) JJA SLP and $850 \mathrm{hPa}$ wind (Asia-AA-SST)

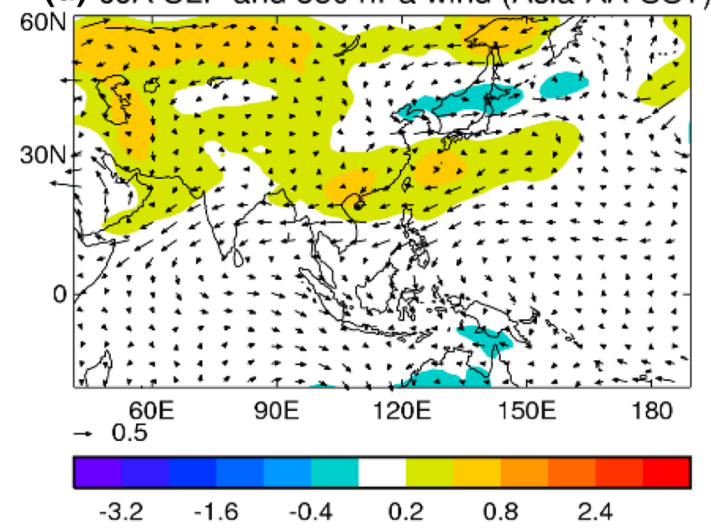

(f) JJA Precipitation change (Asia-AA-SST)

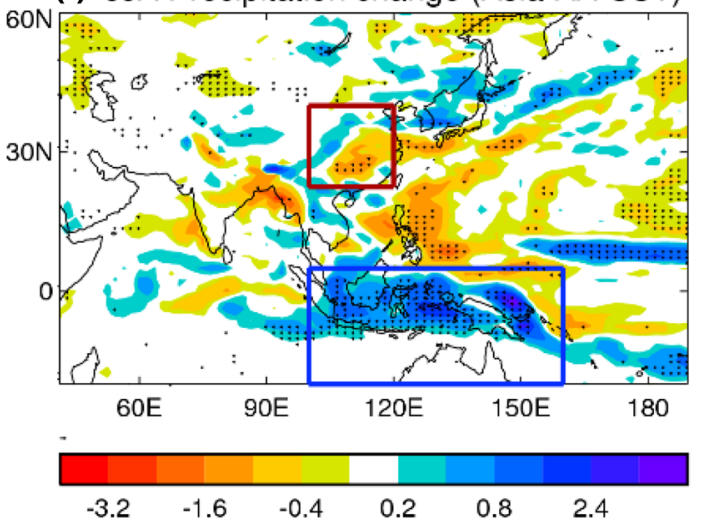

in JJA in response to SST anomalies over the Maritime continents induced by Asian AA change (AMC-ACL). Black lines (a, b) and dots (c, e, f) highlight regions where the changes are statistically significant at the $10 \%$ level using a two-tailed Student's t-test

associated with weakened East Asian summer monsoon (EASM) and reduced precipitation.

- Increased Asian AA emissions induce remote changes over the ocean in boreal winter and spring. These changes play an important role in preconditioning the ocean- 


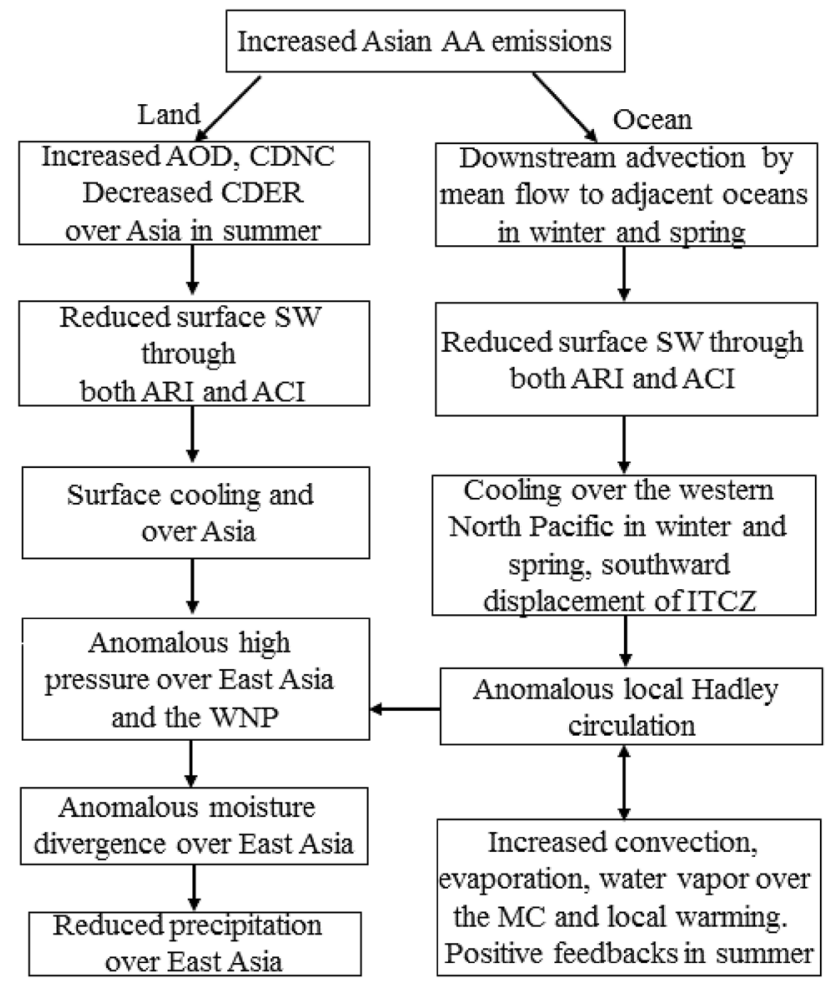

Fig. 14 Schematic diagram illustrating the major processes involved for changes in East Asian summer monsoon and precipitation in response to Asian AA emissions increases from 1970s to 1990s

atmosphere response seen in boreal summer. AA-induced changes in SSTs in the Maritime continent and western North Pacific in boreal summer, and in the meridional SST gradient in the western Pacific, cause a southward shift of the Intertropical Convergence Zone (ITCZ) in the Asian and western Pacific sectors, and changes in the local Hadley circulation. Together with surface responses over the Asian continent, these SST changes shape the responses of circulation and precipitation over East Asia, which are characterized by reduced precipitation over a large land area in East Asia that is driven by anomalous moisture divergence.

- When considering ARI only, the remote response over the tropical and western North Pacific is very weak. Changes in atmospheric circulation are also weak, and the precipitation response over land shows a weak increase (in contrast to the decrease seen in the full response). This indicates that aerosol-cloud interaction plays a dominant role in shaping the pattern and sign of responses in circulation and precipitation over East Asia and the western Pacific to the increased Asian AA emissions from 1970s to 2000s.

- A sensitivity experiment with prescribed SST changes in the Maritime continent further supports the evidence that the remote response of SSTs over the tropical western
Pacific to Asian AA change, which is driven primarily by aerosol-cloud interaction, plays an important role and explains about half of the magnitude in the circulation and precipitation responses to Asian AA increases in boreal summer over East Asia.

In this study, we demonstrate increased Asian AA emissions from 1970s to 2000 s are likely to have played an important role for the southward shift of precipitation during the latter half of the twentieth century, weakening of East Asian summer monsoon (EASM), and reduced precipitation over northern China in East Asia. This southward shift of precipitation over the East Asian and western Pacific sectors is consistent with previous studies that concluded changes in anthropogenic aerosols has been linked to the southward shift of ITCZ, through changes in the cross-equatorial energy transport driven by the aerosol induced interhemispheric contrast in sea surface temperatures (e.g., Hwang et al. 2013; Allen et al. 2015; Voigt et al. 2017; Chung and Soden 2017). Meanwhile, decreased precipitation over northern China and weakened EASM circulation induced by recent increased aerosol emissions over Asia are in agreement with studies on the role of aerosols on the EASM (e.g., Wang et al. 2013, 2017b; Zhang et al. 2017; Tian et al. 2018). We further demonstrate that aerosol-induced SST feedbacks, predominantly through aerosol-cloud interaction (ACI), in both pre-monsoon seasons and summer are key factors in determining the overall circulation and precipitation responses over East Asia and the western North Pacific. This is similar to the findings that the aerosol-induced circulation and precipitation responses over East Asia are mediated by aerosol induced SST changes in some recent studies (e.g., Chen et al. 2016; Kim et al. 2016; Voigt et al. 2017; Wang et al. 2017b; Li et al. 2018).

The changes in East Asian summer circulation in response to Asian AA precursor emissions in this study show some differences in comparison with changes derived from CMIP5 (Song et al. 2014). Song et al. (2014) showed anticyclonic circulation anomalies in middle latitude at about $40^{\circ} \mathrm{N}$ over East Asia and the western Pacific sector and cyclonic circulation anomalies to the south in response to aerosol changes using CMIP5 simulation. However, our study only assesses the role of Asian AA changes from 1970s to 2000s not the changes in global AA emissions as those in Song et al. (2014). Note the circulation changes in our model study bear a similarity to the recent study by Chen et al. (2018) who showed anomalous anticyclonic circulation over the western North Pacific in response to Asian aerosol emission changes from 1850 to 2000 using the community earth system model (CESM) simulations. Therefore, discrepancies in this study from those in CMIP5 simulations not only suggest a model sensitivity of responses in East Asian summer circulation to AA changes, but also suggest that changes in aerosols 
outside Asia might matter for the circulation changes over East Asia.

Our study highlights the importance of ACI and its induced ocean feedbacks to the climate response over East Asia to a change in aerosol emissions. The role of ocean feedbacks implies a limitation of using either regional climate models or AGCMs for studying aerosol impacts on East Asian climate. The importance of ACI also highlights a challenge for modelling studies in view of the large intermodel diversity in the representation of ACI (e.g., Wilcox et al. 2015), and suggests a clear need for greater efforts to reduce ACI uncertainty in climate models.

Acknowledgements This work and LW are supported by UK-China Research and Innovation Partnership Fund through the Met Office Climate Science for Service Partnership (CSSP) China as part of the Newton Fund. BD and RS are supported by the U.K. National Centre for Atmospheric Science-Climate (NCAS-Climate) at the University of Reading. The authors would like to thank two anonymous reviewers for their constructive comments on the early version of the paper.

Open Access This article is distributed under the terms of the Creative Commons Attribution 4.0 International License (http://creativeco mmons.org/licenses/by/4.0/), which permits unrestricted use, distribution, and reproduction in any medium, provided you give appropriate credit to the original author(s) and the source, provide a link to the Creative Commons license, and indicate if changes were made.

\section{References}

Adler RF, Huffman GF, Chang A, Ferraro R, Xie P, Janowiak J, Rudolf B, Schneider U, Curtis S, Bolvin D, Gruber A, Susskind J, Arkin $P$, Nelkin E (2003) The version 2 global precipitation climatology project (GPCP) monthly precipitation analysis (1979-present). J Hydrometeorol 4:1147-1167

Allan R, Ansell T (2006) A new globally complete monthly historical gridded mean sea level pressure dataset (HadSLP2): 1850-2004. J Clim 19:5816-5842

Allen RJ (2015) A 21st century northward tropical precipitation shift caused by future anthropogenic aerosol reductions. J Geophys Res Atmos 120:9087-9102. https://doi.org/10.1002/2015JD023623

Allen RJ, Evan AT, Booth BB (2015) Interhemispheric aerosol radiative forcing and tropical precipitation shifts during the late twentieth century. J Clim 28:8219-8246. https://doi.org/10.1175/ JCLI-D-15-0148.1

Bellouin N, Rae J, Jones A, Johnson C, Haywood J, Boucher O (2011) Aerosol forcing in the climate model intercomparison project (CMIP5) simulations by HadGEM2-ES and the role of ammonium nitrate. J Geophys Res 116:D20206. https://doi.org/10.1029/2011J D016074

Bellouin N, Mann GW, Woodhouse MT, Johnson C, Carslaw KS, Dalvi M (2013) Impact of the modal aerosol scheme GLOMAP-mode on aerosol forcing in the hadley centre global environmental model. Atmos Chem Phys 13:3027-3044. https://doi.org/10.5194/ acp-13-3027-2013

Bollasina MA, Ming Y, Ramaswamy V, Schwarzkopf MD, Naik V (2014) Contribution of local and remote anthropogenic aerosols to the 20th century weakening of the south Asian monsoon. Geophys Res Lett 41:680-687. https://doi.org/10.1002/2013GL058183
Boucher O, Randall D, Artaxo P, Bretherton C, Feingold G, Forster P, Zhang X (2013) Clouds and aerosols. In: Stocker T et al (eds) Climate change 2013: the physical science basis. Contribution of working group I to the fifth assessment report of the intergovernmental panel on climate change. Cambridge University Press, Cambridge, pp 571-657

Cazorla A, Bahadur R, Suski KJ, Cahill JF, Chand D, Schmid B, Ramanathan V, Prather KA (2013) Relating aerosol absorption due to soot, organic carbon, and dust to emission sources determined from in situ chemical measurements. Atmos Chem Phys 13:9337-9350

Chen J-P, Chen I-J, Tsai I-C (2016) Dynamic feedback of aerosol effects on the East Asian summer monsoon. J Clim 29:6137-6149

Chen GX, Wang WC, Chen JP (2018) Circulation responses to regional aerosol climate forcing in summer over East Asia. Clim Dyn. https ://doi.org/10.1007/s00382-018-4267-3

Chou C, Neelin JD, Lohmann U, Feichter J (2005) Local and remote impacts of aerosol climate forcing on tropical precipitation. J Clim 18:4621-4636. https://doi.org/10.1175/JCLI3554.1

Chung E-S, Soden BJ (2017) Hemispheric climate shifts driven by anthropogenic aerosol-cloud interactions. Nat Geosci 10:566571. https://doi.org/10.1038/ngeo2988

Dong B-W, Sutton RT, Highwood E, Wilcox L (2016) Preferred response of the East Asian summer monsoon to local and nonlocal anthropogenic sulphur dioxide emissions. Clim Dyn 46:1733-1751. https://doi.org/10.1007/s00382-015-2671-5

Dong B-W, Sutton RT, Shaffrey L, Klingaman NP (2017) Attribution of forced decadal climate change in coupled and uncoupled ocean-atmosphere model experiments. J Clim 30:6203-6223. https://doi.org/10.1175/JCLI-D-16-0578.1

Giorgi F, Bi XQ, Qian Y (2003) Indirect vs. direct effects of anthropogenic sulfate on the climate of East Asia as simulated with a regional coupled climate-chemistry/aerosol model. Clim Change 58:345-376

Guo L, Highwood EJ, Shaffrey LC, Turner AG (2013) The effect of regional changes in anthropogenic aerosols on rainfall of the East Asian summer monsoon. Atmos Chem Phys 13:1521-1534

Hewitt HT, Copsey D, Culverwell ID, Harris CM, Hill RSR, Keen AB, McLaren AJ, Hunke EC (2011) Design and implementation of the infrastructure of HadGEM3: the next-generation Met Office climate modelling system. Geosci Model Dev 4:223-253

Hirons LC, Klingaman NP, Woolnough SJ (2015) MetUM-GOML: a near-globally coupled atmosphere-ocean-mixed-layer model. Geosci Model Dev 8:363-379. https://doi.org/10.5194/gmd-8363-2015 (ISSN 1991-962X)

Hwang Y-T, Frierson DMW, Kang SM (2013) Anthropogenic sulfate aerosol and the southward shift of tropical precipitation in the late 20th century. Geophys Res Lett 40:2845-2850. https://doi. org/10.1002/grl.50502

Jiang Y, Yang XQ, Liu X (2015) Seasonality in anthropogenic aerosol effects on East Asian climate simulated with CAM5. J Geophys Res Atmos 120(10):837-810,861. https://doi. org/10.1002/2015JD023451

Jones C et al (2011) The HadGEM2-ES implementation of CMIP5 centennial simulations. Geophys Model Dev 4:543-570

Kalnay E, Kanamitsu M, Kistler R, Collins W, Deaven D, Gandin L, Joseph D (1996) The NCEP/NCAR 40-year reanalysis project. Bull Am Meteor Soc 77:437-471

Kim MJ, Yeh SW, Park RJ (2016) Effects of sulfate aerosol forcing on East Asian summer monsoon for 1985-2010. Geophys Res Lett 43:1364-1372. https://doi.org/10.1002/2015GL067124

Lamarque JF et al (2010) Historical (1850-2000) gridded anthropogenic and biomass burning emissions of reactive gases and aerosols: Methodology and application. Atmos Chem Phys 10:7017-7039 
Lamarque JF et al (2011) Global and regional evolution of shortlived radiatively-active gases and aerosols in the representative concentration pathways. Clim Change 109:191-212

Lau KM, Kim KM (2017) Competing influences of greenhouse warming and aerosols on Asian summer monsoon circulation and rainfall. Asia-Pacific. J of Atmos Sci 53:181-194. https:// doi.org/10.1007/s13143-017-0033-4

Lau KM, Kim MK, Kim KM (2006) Aerosol induced anomalies in the Asian summer monsoon: the role of the Tibetan Plateau. Clim Dyn 26:855-864

Levine RC, Turner AG (2012) Dependence of Indian monsoon rainfall on moisture fluxes across the Arabian Sea and the impact of coupled model sea surface temperature biases. Clim Dyn 38:2167-2190. https://doi.org/10.1007/s00382-011-1096-z

Levy H, Horowitz LW, Schwarzkopf MD, Ming Y, Golaz J-C, Naik V, Ramaswamy V (2013) The roles of aerosol direct and indirect effects in past and future climate change. J Geophys Res Atmos 118:4521-4532. https://doi.org/10.1002/jgrd.50192

Li H, Dai A, Zhou T, Lu J (2010) Responses of East Asian summer monsoon to historical SST and atmospheric forcing during 1950-2000. Clim Dyn 34:501-514

Li Z, Lau K-M, Ramanathan V, Wu G, Ding Y, Manoj MG, Brasseur GP (2016) Aerosol and monsoon climate interactions over Asia. Rev Geophys 54:866-929. https://doi.org/10.1002/2015R G000500

Li X, Ting M, Lee DE (2018) Fast adjustments of the Asian summer monsoon to anthropogenic aerosols. Geophy Res Lett 45:10011010. https://doi.org/10.1002/2017GL076667

Liao H, Chang W, Yang Y (2015) Climatic effects of air pollutants over china: a review. Adv Atmos Sci 32:115-139. https://doi. org/10.1007/s00376-014-0013-x

Lin L, Xu Y, Wang Z, Diao C, Dong W, Xie SP (2018) Changes in extreme rainfall over India and China attributed to regional aerosol-cloud interaction during the late 20th century rapid industrialization. Geophys Res Lett 45:7857-7865. https://doi. org/10.1029/2018GL078308

Liu X, Xie X, Yin ZY, Liu C, Gettelman A (2011) A modeling study of the effects of aerosols on clouds and precipitation over East Asia. Theor Appl Climatol 106:343-354

Lu R-Y, Dong B-W (2001) Westward extension of North Pacific subtropical high in summer. J Meteor Soc Jpn 79:1229-1241

Lu Z, Zhang Q, Streets DG (2011) Sulfur dioxide and primary carbonaceous aerosol emissions in China and India, 1996-2010. Atmos Chem Phys 11:9839-9864. https://doi.org/10.5194/ acp-11-9839-2011

Martin GM, Milton SF, Senior CA, Brooks ME, Ineson S, Reichler T, Kim J (2010) Analysis and reduction of systematic errors through a seamless approach to modeling weather and climate. J Clim 23:5933-5957. https://doi.org/10.1175/2010JCLI3541.1

Meehl GA, Arblaster JM, Collins WD (2008) Effects of black carbon aerosols on the Indian monsoon. J Clim 21:2869-2882. https:// doi.org/10.1175/2007JCLI1777.1

Ocko IB, Ramaswamy V, Ming Y (2014) Contrasting climate responses to the scattering and absorbing features of anthropogenic aerosol forcings. J Clim 27:5329-5345

Rayner NA, Parker DE, Horton EB, Folland CK, Alexander LV, Rowell DP, Kent EC, Kaplan A (2003) Global analyses of SST, sea ice and night marine air temperature since the late nineteenth century. J Geophys Res 108. https://doi.org/10.1029/2002J D002670

Rosenfeld D et al (2008) Flood or drought: how do aerosols affect precipitation? Science 321:1309-1313. https://doi.org/10.1126/ science. 1160606

Rosenfeld D et al (2014) Global observations of aerosol-cloud-precipitation-climate interactions. Rev Geophys 52:750-808. https ://doi.org/10.1002/2013RG000441
Smith DM, Murphy JM (2007) An objective ocean temperature and salinity analysis using covariances from a global climate model. J Geophys Res 112:C02022. https://doi.org/10.1029/2005J C003172

Soden B, Chung ES (2017) The large-scale dynamical response of clouds to aerosol forcing. J Clim 30:8783-8794. https://doi. org/10.1175/JCLI-D-17-0050.1

Song F, Zhou T, Qian Y (2014) Responses of East Asian summer monsoon to natural and anthropogenic forcings in the 17 latest CMIP5 models. Geophys Res Lett 41:596-603. https://doi. org/10.1002/2013GL058705

Sperber KR, Annamalai H, Kang IS, Kitoh A, Moise A, Turner A, Wang B, Zhou T (2013) The Asian summer monsoon: an intercomparison of CMIP5 vs. CMIP3 simulations of the late 20th century. Clim Dyn 41:2711-2744. https://doi.org/10.1007/s0038 2-0121607-6

Stevens B, Feingold G (2009) Untangling aerosol effects on clouds and precipitation in a buffered system. Nature 461:607-613. https://doi.org/10.1038/nature08281

Stjern CW, Kristjánsson JE (2015) Contrasting influences of recent aerosol changes on clouds and precipitation in Europe and East Asia. J Clim 28:8770-8790. https://doi.org/10.1175/JCLID-14-00837.1

Tao WK, Chen JP, Li Z, Wang C, Zhang C (2012) Impact of aerosols on convective clouds and precipitation. Rev Geophys 50:RG2001. https://doi.org/10.1029/2011RG000369

Tian F-X, Dong B-W, Robson J, Sutton RT (2018) Forced decadal changes in the East Asian summer monsoon: the roles of greenhouse gases and anthropogenic aerosols. Clim Dyn. https://doi. org/10.1007/s00382-018-4105-7

Tsai I, Wang WC, Hsu HH, Lee WL (2016) Aerosol effects on summer monsoon over Asia during 1980s and 1990s. J Geophys Res Atmos 121:11761-11776. https://doi.org/10.1002/2016JD025388

Twomey S (1977) Influence of pollution on shortwave albedo of clouds. J Atmos Sci 34:1149-1152

Voigt A, Pincus R, Stevens B, Bony S, Boucher O, Bellouin N, Lewinschal A, Medeiros B, Wang Z, Zhang H (2017) Fast and slow shifts of the zonal-mean intertropical convergence zone in response to an idealized anthropogenic aerosol. J Adv Model Earth Syst 9: 870-892. https://doi.org/10.1002/2016MS000902

Walters DN, Best MJ, Bushell AC, Copsey D, Edwards JM, Falloon PD, Roberts MJ et al (2011) The Met Office Unified Model global atmosphere 3.0/3.1 and Jules global land 3.0/3.1 configurations. Geosci Model Dev 4:919. https://doi.org/10.5194/ gmd-4-919-2011

Wang B (2006) The Asian Monsoon. Springer/Praxis Publishing Co., New York, $\mathrm{p} 787$

Wang T, Wang H, Otterå OH, Gao Y, Suo L, Furevik T, Yu L (2013) Anthropogenic forcing of shift in precipitation in Eastern China in late 1970s. Atmos Chem Phys Discuss 13:1199-712032. https ://doi.org/10.5194/acpd-13-11997-2013

Wang C, Zhang L, Lee S-K, Wu L, Mechoso CR (2014) A global perspective on CMIP5 climate model biases. Nat Clim Change 4:201-205. https://doi.org/10.1038/nclimate2118

Wang Y, Jiang JH, Su H (2015) Atmospheric responses to the redistribution of anthropogenic aerosols. J Geophys Res Atmos 120:9625-9641. https://doi.org/10.1002/2015JD023665

Wang Q, Wang Z, Zhang H (2017a) Impact of anthropogenic aerosols from global, East Asian, and non-East Asian sources on East Asian summer monsoon system. Atmos Res 183:224-236. https ://doi.org/10.1016/j.atmosres.2016.08.023

Wang Z, Lin L, Yang M, Xu Y, Li J (2017b) Disentangling fast and slow responses of the East Asian summer monsoon to reflecting and absorbing aerosol forcings. Atmos Chem Phys 17:1107511088. https://doi.org/10.5194/acp-17-11075-2017 
Wang Z, Wang Q, Zhang H (2017c) Equilibrium climate response of the East Asian summer monsoon to forcing of anthropogenic aerosol species. J Meteorol Res 31:1018-1033. https://doi. org/10.1007/s13351-017-7059-5

Wilcox LJ, Highwood EJ, Booth BBB, Carslaw KS (2015) Quantifying sources of inter-model diversity in the cloud albedo effect. Geophys Res Lett 42:1568-1575. https://doi.org/10.1002/2015G L063301 ISSN 0094-8276

Wilcox L, Dunstone N, Lewinschal A, Bollasina M, Ekman A, Highwood E (2018) Mechanisms for a remote response to Asian aerosol emissions in boreal winter. Atmos Chem Phys Discuss. https ://doi.org/10.5194/acp-2018-980 (ISSN 1680-7375)

Wu GX, Li ZQ, Fu CB, Zhang XY, Zhang RY, Zhang RH, Zhou TJ, Li JP, Li JD, Zhou DG, Wu L, Zhou LT, He B, Huang RH (2015) Advances in studying interactions between aerosols and monsoon in China. Sci China Earth Sci. https://doi.org/10.1007/s1143 0-015-5198-z

Xie X, Liu X, Wang H, Wang Z (2016a) Effects of aerosols on radiative forcing and climate over East Asia with different $\mathrm{SO}_{2}$ emissions. Atmosphere 7:99. https://doi.org/10.3390/atmos7080099

Xie X, Wang H, Liu X, Li J, Wang Z, Liu Y (2016b) Distinct effects of anthropogenic aerosols on the East Asian summer monsoon between multidecadal strong and weak monsoon stages. J Geophys
Res Atmos 121:7026-7040. https://doi.org/10.1002/2015JD0242 28

Xu Y, Xie SP (2015) Ocean mediation of tropospheric response to reflecting and absorbing aerosols. Atmos Chem Phy 15:58275833. https://doi.org/10.5194/acp-15-5827-2015

Yan Z, Lin Z, Zhang H (2014) The relationship between the East Asian subtropical westerly jet and summer precipitation over East Asia as simulated by the IAP AGCM4.0. Atmos Oceanic Sci Lett 7(6):487-492

Zhang L, Li T (2016) Relative roles of anthropogenic aerosols and greenhouse gases in land and oceanic monsoon changes during past 156 years in CMIP5 models. Geophys Res Lett 43:52955301. https://doi.org/10.1002/2016GL069282

Zhang L, Wu P, Zhou T (2017) Aerosol forcing of extreme summer drought over North China. Environ Res Lett 12:034020. https:// doi.org/10.1088/1748-9326/aa5fb3

Publisher's Note Springer Nature remains neutral with regard to jurisdictional claims in published maps and institutional affiliations. 